\title{
Tubular dual-layer MFI zeolite membrane reactor for hydrogen production via the WGS reaction: Experimental and modeling studies
}

\author{
Xueliang Dong ${ }^{1}$, Haibing Wang ${ }^{1}$, Zebao Rui ${ }^{2}$, Y.S. Lin ${ }^{1} *$ \\ 1-School for Engineering of Matter, Transport and Energy, \\ Arizona State University, Tempe, Arizona 85287, USA \\ 2-Department of Chemical Engineering, \\ Sun Yat-Sen University, Guangzhou 510275, China
}

*Corresponding author.

Tel.: +1 4809657769 ,

Fax: +1 4809650037 .

E-mail address: jerry.lin@asu.edu (Y.S. Lin). 


\begin{abstract}
Water-gas shift (WGS) reaction is an important intermediate step in converting fossil fuels to hydrogen $\left(\mathrm{H}_{2}\right)$ for chemical production or power generation. Catalytic membrane reactor with a $\mathrm{H}_{2}$ perm-selective membrane can improve WGS reaction conversion and separate $\mathrm{H}_{2}$ from carbon dioxide $\left(\mathrm{CO}_{2}\right)$ simultaneously. In this work, experimental work and modeling analysis were performed on WGS in a tubular ZSM-5/silicalite bilayer membrane composed of a $3 \mu \mathrm{m}$ ZSM-5 layer, a $8 \mu \mathrm{m}$ silicalite base layer and a $2 \mu \mathrm{m}$ YSZ barrier layer supported on $\alpha$-alumina substrate. The experimental and modeling studies demonstrated that temperature, $\mathrm{H}_{2} \mathrm{O} / \mathrm{CO}$ ratio, gas hourly space velocity (GHSV) and feed pressure are key factors that determine the WGS performance in the tubular zeolite membrane reactor. At $500{ }^{\circ} \mathrm{C}$ and under 5 atm with the $\mathrm{H}_{2} \mathrm{O} / \mathrm{CO}$ ratio of 3.0 and GHSV of $72000 \mathrm{~h}^{-1}$, the $\mathrm{CO}$ conversion and $\mathrm{H}_{2}$ recovery reached $89.8 \%$ and $28.5 \%$, respectively. Appropriate temperature, pressure, $\mathrm{H}_{2} \mathrm{O} / \mathrm{CO}$ ratio and GHSV are crucial to obtain high reaction performance. Modeling analysis coupled with experimental data identifies the optimum operation conditions $\left(550{ }^{\circ} \mathrm{C}\right.$, feed pressure of $20 \mathrm{~atm}, \mathrm{H}_{2} \mathrm{O} / \mathrm{CO}$ ratio of 2.0 , GHSV of $60000 \mathrm{~h}^{-1}$ ) under which one can achieve both high CO conversion (>95\%) and $\mathrm{H}_{2}$ recovery ( $>90 \%)$ for WGS in this zeolite membrane reactor.
\end{abstract}

Keywords: Zeolite membranes; Tubular membranes; Water gas shift; Hydrogen separation; Modeling. 


\section{Introduction}

Water-gas shift (WGS) reaction is a key step in many chemical processes for $\mathrm{H}_{2}$ production from fossil and biofuels, which allows further conversion of the intermediately formed $\mathrm{CO}$ with $\mathrm{H}_{2} \mathrm{O}$ to $\mathrm{H}_{2}$ and $\mathrm{CO}_{2}$ [1]. WGS is a moderately exothermic, reversible and thermodynamic equilibrium limited reaction, especially at high temperature. Commercial WGS is carried out in multiple stage reactors operated at different temperatures. For example, for a two-reactor process, the high-temperature shift reactor is operated at $350-450{ }^{\circ} \mathrm{C}$ with an iron-based catalyst, while the low-temperature shift reactor is operated at $190-250{ }^{\circ} \mathrm{C}$ using a copper-zinc oxide catalyst [2]. Removing one of the products (i.e. $\mathrm{H}_{2}$ or $\mathrm{CO}_{2}$ ) from the WGS reaction zone can break the equilibrium limitation and significantly enhance the $\mathrm{CO}$ conversion. Therefore, numerous studies are focused on catalytic membrane reactors for WGS reaction accompanied by the simultaneous separation of $\mathrm{H}_{2}$ or $\mathrm{CO}_{2}$ [3-8].

Majority of the WGS membrane reactors are fabricated based on the $\mathrm{H}_{2}$ separation membranes [3-5]. The $\mathrm{H}_{2}$ removal from the reactor facilitates high $\mathrm{CO}$ conversion at a given temperature, thus a non-permeate stream comprising mainly $\mathrm{CO}_{2}$ can be obtained. This arrangement would represent considerable simplification of the process: using a single stage shift reactor to produce high purity $\mathrm{H}_{2}$ without or with only minimum additional separation/purification efforts. This will reduce the duty of the scrubbing system and deliver $\mathrm{CO}_{2}$ at high pressure which minimizes the cost of $\mathrm{CO}_{2}$ capture. However, stability is one of the key issues of WGS membrane reactors. WGS reaction is usually operated at relatively high temperature and pressure. Steam and some corrosive gases are included, such as $\mathrm{H}_{2} \mathrm{~S}$. Therefore, high thermal, mechanical and chemical stability of the membranes are required for the WGS membrane reactors. To date, several types of inorganic membranes, such as Pd and Pd-based alloy membranes [9-13], silica membranes [14-16], and zeolite membranes [17-21], have been studied as WGS membrane reactors for $\mathrm{H}_{2}$ production. 
$\mathrm{Pd}$ and Pd-based alloy membranes exhibit high $\mathrm{H}_{2}$ permeability and excellent selectivity. Lee et al.[10] developed a pilot-scale WGS reactor $\left(1 \mathrm{Nm}^{3} \cdot \mathrm{h}^{-1}\right.$ feed gas) using Pd-Cu membranes. The $\mathrm{CO}_{2}$ concentration of retentate flow reached 80 vol. $\%$ and the $\mathrm{H}_{2}$ concentration of permeate flow was over 99 vol.\%. Catalano et al. [11] studied the scaling up of Pd-based WGS membrane reactor with $0.02 \mathrm{~m}^{2}$ of effective membrane area. A maximum CO conversion of $98.1 \%$ was achieved, with a $\mathrm{H}_{2}$ recovery of $81.5 \%$ and $\mathrm{H}_{2}$ purity of $99.97 \%$ at $440{ }^{\circ} \mathrm{C}$ and 20 bar of absolute pressure in the retentate side. The disadvantages of Pd-based membranes lie in their moderate durability and high brittleness which limit their practical applications [22,23].

Amorphous microporous silica membranes synthesized by sol-gel or chemical vapor deposition technologies show good $\mathrm{H}_{2}$ permeance and selectivity over other gases. Brunetti et al.[14] studied the WGS reaction in a porous stainless steel supported silica membrane reactor. A CO conversion of $95 \%$ and $\mathrm{H}_{2} / \mathrm{CO}_{2}$ selectivity of 40 were achieved at $280{ }^{\circ} \mathrm{C}$ and 4 bar. However, the microporous silica membranes are unstable under hydrothermal environment. When exposed to humid gas stream at elevated temperatures, the continuous hydrolysis and condensation of the silica network results in the widening and eventual collapse of the pore structure, and drastically decrease of $\mathrm{H}_{2}$ separation performance [24,25]. In attempt to address this problem, recent efforts were focused on the development of metal doped silica membranes, such as Ni-, Co- and Nb-doped membranes [15,16,26-28]. Although the doped membranes exhibited an improved hydrothermal stability (up to $300 \mathrm{~h}$ ) [28], they were still not suitable for long-term industrial applications.

Recent research on crystalline microporous MFI-type zeolite membranes opened up a new direction in developing microporous membranes for high temperature $\mathrm{H}_{2}$ separation from WGS reaction [17-21]. MFI-type zeolite membranes exhibit good thermal and chemical stability. However, the pore size (around $0.55 \mathrm{~nm}$ ) is relatively large for selective separation of $\mathrm{H}_{2}$, resulting in high permeance but low selectivity [29-32]. To reduce the pore size of MFI-type 
zeolite, a silane modification strategy was developed by Masuda et al.[33] The precursor molecules of silane were introduced into the zeolitic pores and chemisorbed on the active sites (acid sites and metal cations). After a catalytic cracking process, the mono $\mathrm{SiO}_{2}$ unit was left on the active sites to reduce the zeolitic pore size. This modification technique has been studied to adjust the effective diameter of mass transport channels in zeolite membranes and to reduce the intercrystalline defects of membranes [30-32,34-37]. A recent improvement in this method was reported by Dong and Lin and their co-workers [32,36] on controlled modification of zeolitic pores of a zeolite membrane to improve hydrogen selectivity with minimum reduction in $\mathrm{H}_{2}$ permeance.

MFI-type zeolite membranes with improved $\mathrm{H}_{2} / \mathrm{CO}_{2}$ selectivity were also used for WGS membrane reactors. Tang et al. [17] fabricated a modified MFI zeolite tubular membrane reactor for WGS. At $550{ }^{\circ} \mathrm{C}$ with a WHSV of $60,000 \mathrm{~h}^{-1}$ and a $\mathrm{H}_{2} \mathrm{O} / \mathrm{CO}$ ratio of 1.0 , CO conversion of $81.7 \%$ was achieved, which was significantly higher than that obtained in the traditional packed-bed reactor. The study examined the effects of reaction conditions such as temperature and space velocity on WGS reaction in the membrane reactor. However, the effect of the pressure, a critical parameter of great importance for practical application, was not studied in this work. Subsequently the effect of pressure on the WGS reaction performance in the zeolite membrane reactor was investigated by both experiment and modeling, but the studies were conducted only on disk zeolite membrane reactor $[18,19]$. The availability of the stable tubular bilayer zeolite membranes, coupled with the use of a mathematical model, allowed us to study operation of WGS in the zeolite membrane reactor under conditions more close to the practical applications.

Recently, we succeeded in synthesis of disk shaped ZSM-5/silicalite bilayer membranes for $\mathrm{H}_{2}$ separation and WGS membrane reactor $[21,36]$. The bilayer structure of the zeolite membranes allowed better control of zeolite membrane modification for improved separation performance. 
More excitingly, the bilayer MFI zeolite membranes exhibited unprecedented high thermal and chemical stability under industrial relevant WGS atmospheres even with 400 ppm $\mathrm{H}_{2} \mathrm{~S}$ at about $500{ }^{\circ} \mathrm{C}$ because of the unique properties of MFI-type zeolite and the specific structure design [21]. It was a logic next step for us to synthesize bilayer MFI zeolite membranes in tubular geometry in an effort to explore the use of the stable zeolite membranes for WGS reaction applications.

It should be noted that many experimental and modeling studies on WGS in membrane reactors, mostly of Pd alloy membranes, were reported by other researchers [4,5]. The results of those studies on metal membrane reactors could not be directly used to predict the performance of WGS in the zeolite membrane reactor because of the difference in permeation and separation mechanisms between these membranes. As reviewed above, limited studies on WGS in microporous (e.g. silica) membrane reactors were also reported, but these studies were conducted at low pressures $(<4$ atm). In practical applications, WGS zeolite membrane reactor is likely to be operated at high pressures ( $>20 \mathrm{~atm})$ with high pressure raw syngas from a gasifer as the feed. However, the effect of operation pressure on WGS reaction in a tubular zeolite membrane is not

clear. Since it is more difficult to perform WGS in microporous membrane reactor at high pressures, a mathematical model, with values for the parameters obtained from the low pressure experimental data, was set up and used to predict WGS performance of the zeolite membrane reactor at high pressures. The objective of this paper is to report synthesis of the new bilayer MFI zeolite membrane in the tubular geometry, and experimental and modeling study of WGS in the tubular zeolite membrane reactor with focus on examining the effects of the pressure on and optimum conditions for WGS in tubular zeolite membrane reactor.

\section{Experimental}

2.1 Synthesis of tubular ZSM-5/silicalite bilayer membrane 
Porous alumina tubes (PALL Corporation) with the length of $8 \mathrm{~cm}$, inner and outer diameters of $0.7 \mathrm{~cm}$ and $1.0 \mathrm{~cm}$, respectively, were used as supports. The average porous size of the inner layer of the alumina support was $200 \mathrm{~nm}$. The inner surface was modified with an yttria-stabilized zirconia (YSZ) intermediate barrier layer to prevent the diffusion of $\mathrm{Al}^{3+}$ into zeolite membrane layer [38]. The YSZ suspension was synthesized following the procedure in our previous work [38,39]. YSZ barrier layer was prepared via a dip-coating process and followed by a calcination step at $1000{ }^{\circ} \mathrm{C}$ for $3 \mathrm{~h}$ in air [36]. The outer side of the tube was covered with Teflon tape during the dip-coating to avoid the deposition of YSZ. After YSZ modification, two ends of the alumina tube were coated with glaze and the middle of the support about $1.5 \mathrm{~cm}$ in length was left for membrane synthesis.

Silicalite seed was coated onto the surface of YSZ barrier layer by a dip-coating process. The detailed procedure for the preparation of silicalite seed and seed suspension can be found in our previous work [40]. The silicalite layer was then synthesized on the seeded support via a secondary growth process using a precursor with the molar composition of $0.9 \mathrm{NaOH}$ : 0.9 TPABr: $4 \mathrm{SiO}_{2}$ : $1000 \mathrm{H}_{2} \mathrm{O}: 16 \mathrm{EtOH}$ at $175{ }^{\circ} \mathrm{C}$ for $8 \mathrm{~h}$ [36]. The as-prepared silicalite membrane was washed and dried, then calcined at $500{ }^{\circ} \mathrm{C}$ for $8 \mathrm{~h}$ in air to remove the organic template. Subsequently, a thin ZSM-5 top layer was fabricated on the silicalite layer via a hydrothermal process at $180{ }^{\circ} \mathrm{C}$ for $8 \mathrm{~h}$ using a template-free precursor with a composite of $5 \mathrm{~g} \mathrm{SiO}_{2}, 60 \mathrm{~g} \mathrm{H}_{2} \mathrm{O}$, $1.15 \mathrm{~g} \mathrm{NaOH}$, and $0.65 \mathrm{~g} \mathrm{Al}_{2}\left(\mathrm{SO}_{4}\right)_{3} \cdot 18 \mathrm{H}_{2} \mathrm{O}$ [36].

To adjust the zeolitic pore size and improve the $\mathrm{H}_{2}$ selectivity, the tubular ZSM-5/silicalite bilayer membrane was modified through an in situ catalytic cracking deposition (CCD) process of methyldiethoxysilane (MDES) precursor [21,36]. MDES precursor was carried into the tube side of the bilayer membrane by an equimolar $\mathrm{H}_{2} / \mathrm{CO}_{2}$ mixture gas. Helium was introduced to another side as sweep gas. The MDES molecules adsorbed onto the active sites (framework $\mathrm{Al}^{3+}$ generated acidic sites) on the inner surface of the zeolitic pore channels. At about $450{ }^{\circ} \mathrm{C}$, the 
adsorbed MDES molecules decomposed and deposited as $\mathrm{SiO}_{2}$ units on active sites thereby reduce the zeolitic pore size [33]. The components of permeate stream were continuously analyzed by a gas chromatography (GC, Agilent 6890 N with a column of HayeSep DB 100/120, AllTech).

\subsection{Characterization}

The crystal structure of the membranes was characterized by X-ray diffraction (XRD, Bruker AXS-D8, Cu Ka radiation). Diffraction patterns were collected at room temperature in the range of $5^{\circ}<2 \theta<45^{\circ}$, with a step width of $0.05^{\circ}$ and a scan rate of $0.2 \mathrm{~s}$ per step. The morphology of the ZSM-5/silicalite bilayer membranes were characterized using a scanning electron microscopy (SEM, Philips, XL 30).

\subsection{WGS reaction}

About $0.2 \mathrm{~g}$ Fe-Cr-Cu catalyst (with the atomic ratio of 10:1:0.25), prepared following the reported procedures [21,41], was packed into the tube side of the ZSM-5/silicalite bilayer membrane for WGS reaction. The catalyst was fixed at the middle of the tube by glass wool at two sides, as shown in Figure 1a. The membrane was then assembled into a stainless steel tubular membrane cell using soft graphite for sealing. Before WGS reaction, the catalyst was activated at $400{ }^{\circ} \mathrm{C}$ for $4 \mathrm{~h}$ using a mixed gas with the composition of $33.3 \% \mathrm{CO}, 25.0 \% \mathrm{CO}_{2}$, $25.0 \% \mathrm{H}_{2}$ and $16.7 \%$ steam. The schematic diagram of the set-up for WGS reaction was shown in Figure 1b. CO and water were introduced into the tube side of the membrane. The water flow rate was controlled by a precisely calibrated liquid pump (LC-20AD, Shimadzu Corporation). WGS reaction occurred at the catalyst bed. The produced $\mathrm{H}_{2}$ permeated through the zeolite membrane to the shell side and was swept out by Argon (Ar). The compositions of feed out and sweep out streams were analyzed using GC. The flow rates of the effluents from both feed and sweep gases were measured by a soap film flow meter. The $\mathrm{CO}$ conversion and $\mathrm{H}_{2}$ recovery are calculated by the following equations, respectively. 


$$
\begin{aligned}
X_{C O} & =\frac{F_{C O}^{\text {feed in }}-F_{C O}^{\text {feed out }}-F_{C O}^{\text {sweep out }}}{F_{C O}^{\text {feed in }}} \\
R_{\mathrm{H}_{2}} & =\frac{F_{\mathrm{H}_{2}}^{\text {sweep out }}}{F_{\mathrm{H}_{2}}^{\text {feed out }}+F_{\mathrm{H}_{2}}^{\text {sweep out }}}
\end{aligned}
$$

where $F_{C O}^{\text {feed in }}, F_{C O}^{\text {feed out }}$ and $F_{C O}^{\text {sweep out }}$ are $\mathrm{CO}$ flow rates $\left(\mathrm{mL} \cdot \mathrm{min}^{-1}\right)$ in feed in, feed out and sweep out streams, respectively; $F_{H_{2}}^{\text {feed out }}$ and $F_{H_{2}}^{\text {sweep out }}$ are $\mathrm{H}_{2}$ flow rates $\left(\mathrm{mL} \cdot \mathrm{min}^{-1}\right)$ in feed out and sweep out streams, respectively.

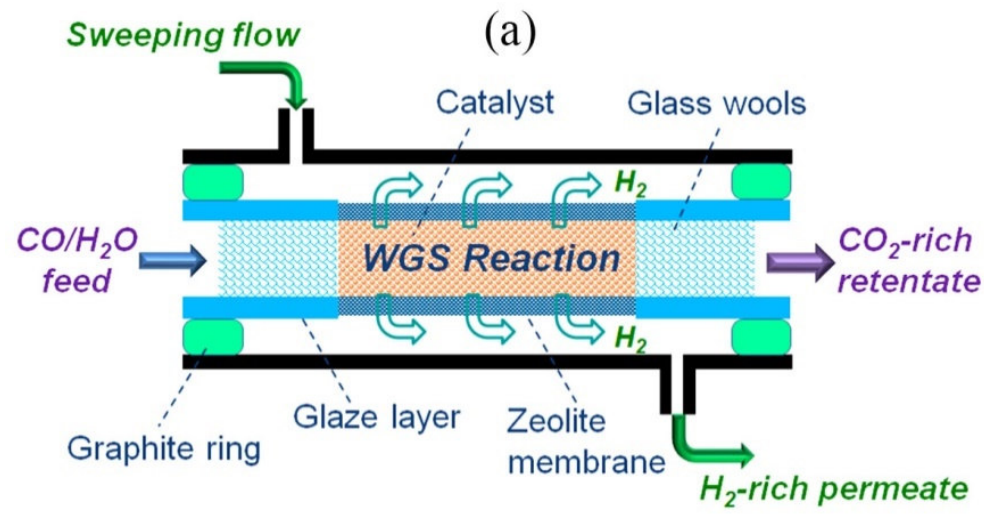

(b)

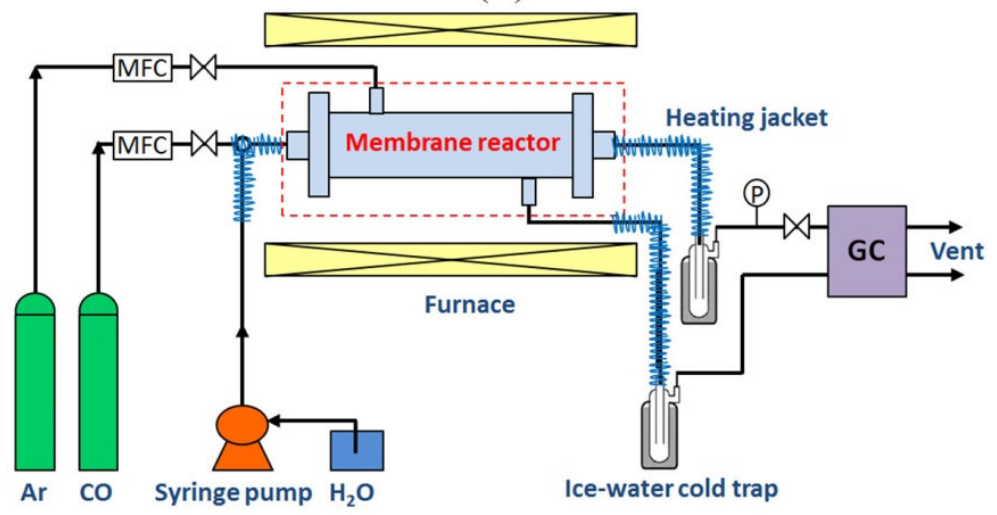

Figure 1 Schematic diagram of tubular membrane cell (a) and membrane reactor set-up (b) for WGS reaction. 


\section{Modeling}

\subsection{Kinetic equation}

The empirical power-law equation was widely applied as the WGS reaction rate equation because of its simplicity and effectiveness in correlating the experimental data of WGS reaction over iron-based catalyst [42]. Considering that the $\mathrm{Fe}-\mathrm{Cr}-\mathrm{Cu}$ catalyst was used in our experiments, the following power-law WGS reaction rate equation developed by Hla et al. [42] based on commercial Fe-Cr-Cu catalyst was used to describe the WGS kinetics in this study.

$$
r_{A}=10^{0.659} \exp \left(\frac{-8.8 \times 10^{4}}{R T}\right) P_{C O}^{0.9} P_{H_{2} O}^{0.31} P_{C O_{2}}^{-0.156} P_{H_{2}}^{-0.05}\left(1-\frac{1}{K_{e q}} \frac{P_{C_{2} O_{2} P_{2}}}{P_{C O} P_{H_{2}} \mathrm{O}}\right)
$$

where $r_{A}$ is the reaction rate $\left(\mathrm{mol} \cdot \mathrm{g}_{\mathrm{cat}}{ }^{-1} \cdot \mathrm{s}^{-1}\right), R$ is the gas constant, $T$ is the temperature $(\mathrm{K}), P_{i}$ is the partial pressure of component $i$ in the reaction zone $(\mathrm{Pa}) . K_{e q}$ is the temperature-dependent thermodynamic equilibrium constant for WGS, which can be defined as

$$
K_{e q}=\exp \left(\frac{4577.8}{T}-4.33\right)
$$

\subsection{Permeation equations}

The membrane permeance for each gas $\left(\mathrm{H}_{2} \mathrm{O}, \mathrm{CO}, \mathrm{H}_{2}, \mathrm{CO}_{2}\right.$ and $\left.\mathrm{Ar}\right)$ in the WGS reaction can be expressed as[43]

$$
j_{i}=\frac{\varphi}{\delta}\left(D_{i} \beta_{i}\right)
$$

where $j_{i}$ is the permeance of component $i$ through the membrane $\left(\mathrm{mol} \cdot \mathrm{m}^{-2} \cdot \mathrm{s}^{-1} \cdot \mathrm{Pa}^{-1}\right), \varphi$ is ratio of membrane porosity $(\sim 0.25)$ to tortuosity factor $(\sim 5)$, which has the value of 0.05 as reported by Kanezashi and Lin,[44] $\delta$ is the thickness of the membrane (m), $D_{i}$ is the diffusivity of gas $i$ in zeolite $\left(\mathrm{m}^{2} \cdot \mathrm{s}^{-1}\right)$, and $\beta_{i}$ is the adsorption equilibrium constant of gas $i$.

For diffusion of small gases with weak adsorption affinity with zeolites, following gas translational diffusion model was proposed to predict diffusivity in zeolite pores [45] 


$$
D_{i}=\frac{\alpha}{\lambda}\left(\frac{8 R T}{\pi M_{i}}\right)^{1 / 2} \exp \left(\frac{-E_{d, i}}{R T}\right)
$$

where $\alpha$ is the diffusion length or distance between two adjacent sites (m), which is about $1 \mathrm{~nm}$ for diffusion in MFI-type zeolite [44], $\lambda$ is the diffusion coordination number (4 for MFI-type zeolite), $M_{i}$ is the molecular weight of the diffusing gas $\left(\mathrm{g} \cdot \mathrm{mol}^{-1}\right), E_{d, i}$ is the activation energy for diffusion of the gas $i$ in the micropores $\left(\mathrm{kJ} \cdot \mathrm{mol}^{-1}\right)$, which is determined by the relative size of diffusing gas molecule to the zeolite pore size. The typical values of $E_{d, i}$ are $13.39,13.14,12.55$ and $14.97 \mathrm{~kJ} \cdot \mathrm{mol}^{-1}$ for $\mathrm{H}_{2}, \mathrm{CO}, \mathrm{CO}_{2}$ and Ar, respectively [32].

At elevated temperatures, $\beta_{i}=1 / \mathrm{RT}$ [43], inserting Eq. 6 into Eq. 5 gives

$$
j_{i}=\frac{\varphi}{\delta} \frac{\alpha}{\lambda}\left(\frac{8}{\pi R T M_{i}}\right)^{1 / 2} \exp \left(\frac{-E_{d, i}}{R T}\right)
$$

From our previous experiment results [21], $\mathrm{H}_{2} \mathrm{O}$ vapor permeance through ZSM-5/silicalite bilayer membrane was relatively low and the $\mathrm{H}_{2} / \mathrm{H}_{2} \mathrm{O}$ selectivity reached 180 at $500{ }^{\circ} \mathrm{C}$. Therefore, the $\mathrm{H}_{2} \mathrm{O}$ vapor permeation through the membrane will not be considered in the modeling study.

\subsection{Membrane reactor model}

Some hypotheses and definitions were made to simplify the calculation: (1) one-dimensional tubular reactor without radial concentration gradients on both the tube and shell sides. (2) No gas film resistance for mass transfer through the membrane walls and negligible mass transfer resistances through the porous support and through catalyst bed. This hypothesis is justified by the relatively low $\mathrm{H}_{2}$ permeation flux of the modified MFI zeolite membrane and the fact that the pore sizes of the porous support and the catalyst bed are much larger than that of the modified MFI zeolite layer. (3) A steady state, isothermal operation, with a same inlet temperature for the sweep gas and reactant mixture. (4) Ideal gas law is used to describe the gas behaviors of the single component and gas mixture. (1), (3) and (4) are general assumptions and have been widely used for the modeling study of WGS reaction in membrane reactors [46-49]. 
According to the principle of mass conservation, the design model equations are derived in each region as follows.

$$
\frac{d F_{i}}{d z}=\pi r^{2} \rho_{B} v_{i} r_{A}-2 \pi r j_{i} \Delta P_{i}
$$

where $F_{i}\left(i=\mathrm{CO}, \mathrm{CO}_{2}, \mathrm{H}_{2}, \mathrm{Ar}\right)$ is the molar flow rate in the tube side $\left(\mathrm{mol} \cdot \mathrm{s}^{-1}\right), v_{i}$ the stoichiometry of species $i$ in WGS reaction, $v_{H e}=0, \Delta P_{i}$ is the partial pressure difference of specie $i$ between the tube side and the shell side $(\mathrm{Pa})$.

In the shell side:

$$
\frac{d Q_{i}}{d z}=2 \pi r j_{i} \Delta P_{i}
$$

where $Q_{i}$ is the molar flow rate in the shell side $\left(\mathrm{mol} \cdot \mathrm{s}^{-1}\right)$. A one-dimensional reaction model for the traditional fixed-bed reactor for WGS was established by setting $j_{i}=0$ in Eqs. 8 and 9.

Eqs. 8 and 9 are eight ordinary differential equations, of which the solutions give profiles of 8 variables $\left(\mathrm{F}_{\mathrm{CO}}, \mathrm{F}_{\mathrm{CO} 2}, \mathrm{~F}_{\mathrm{H} 2}, \mathrm{~F}_{\mathrm{Ar}}, \mathrm{Q}_{\mathrm{CO}}, \mathrm{Q}_{\mathrm{CO} 2}, \mathrm{Q}_{\mathrm{H} 2}, \mathrm{Q}_{\mathrm{Ar}}\right)$ along the longitudinal direction of the membrane reactor. The differential equations, with adequate boundary conditions at $\mathrm{z}=0$ and the values of the parameters listed in Table 1, were solved using a numerical Rung-Kutta method. The calculation was performed on MATLAB 2012a (MathWorks, Inc., Natick, US).

Table 1 Values for parameters used in the simulation

\begin{tabular}{lc}
\hline Parameters & Reference values \\
\hline Temperature $\left({ }^{\circ} \mathrm{C}\right)$ & $400-550$ \\
Feed side pressure $(\mathrm{atm})$ & $1-30$ \\
Permeate side pressure $(\mathrm{atm})$ & 1 \\
Weight of the catalyst $(\mathrm{g})$ & 0.2 \\
Average diameter of the catalyst particles $(\mathrm{m})$ & $2.5 \times 10^{-4}$ \\
Thickness of the MFI-type zeolite membrane (ZSM-5 & $3.0 \times 10^{-6}$ \\
layer) $(\mathrm{m})$ & \\
Inner radial of the membrane $(\mathrm{m})$ & $3.5 \times 10^{-3}$ \\
Length of the membrane $(\mathrm{m})$ & $1.5 \times 10^{-2}$ \\
CO feed flow rate $\left(\mathrm{mL} \cdot \mathrm{min}^{-1}\right)$ & $20-50$ \\
Steam to CO ratio & $1-3$ \\
Ar sweep flow rate $\left(\mathrm{mL} \cdot \mathrm{min}^{-1}\right)$ & $20-50$ \\
\hline
\end{tabular}




\section{Results and discussion}

4.1 Structure and separation performance of tubular ZSM-5/silicalite bilayer membranes

During the preparation of ZSM-5/silicalite bilayer membrane, the crystal structure of each layer of the tubular membrane (on inner surface) was analyzed, as shown in Figure 2. Silicalite layer (Figure 2c) and the ZSM-5/silicalite bilayer membrane (Figure 2d) exhibit typical MFI-type zeolite crystal structure [21,50]. The diffraction peaks of YSZ modified alumina support can also be observed, indicating the relatively small thickness of the zeolite layer. In addition, no obvious impurity phases are found. Therefore, zeolite membrane of pure MFI-type has been successfully fabricated on the tubular support.

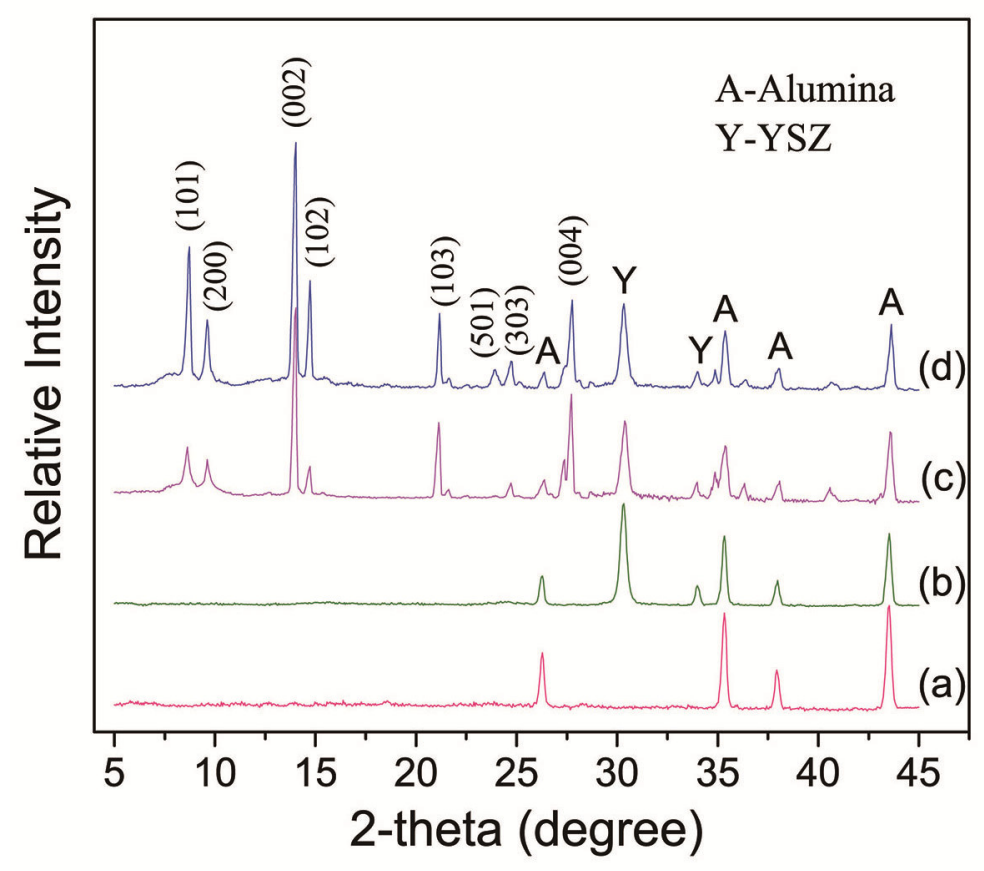

Figure 2 XRD patterns of tubular (a) alumina support; (b) YSZ modified alumina support; (c) silicalite membrane on YSZ/alumina support; (d) ZSM-5/silicalite bilayer membrane on YSZ/alumina support.

The morphology of the ZSM-5/silicalite bilayer membranes was further analyzed to evaluate 
their quality. Nanosized YSZ particles are deposited on the surface of alumina support, forming the crack-free and uniform YSZ layer (Figure 3a). An intergrown silicalite layer composed of sharp grains with the size of about $2 \mu \mathrm{m}$ is synthesized on the YSZ layer (Figure 3b). The surface of the membrane (Figure 3c) is covered by continuous and highly intergrowth ZSM-5 grains with the grain size of 1-2 $\mu \mathrm{m}$. No obvious defect could be observed. The ZSM-5 grains are not as sharp as that of the silicalite because of the template-free synthesis $[39,44]$. Figure 3d shows clear and crack-free alumina, YSZ, silicalite and ZSM-5 layers. These layers are well bonded together. The thicknesses of YSZ, silicalite and ZSM-5 layers are $2 \mu \mathrm{m}, 8 \mu \mathrm{m}$ and $3 \mu \mathrm{m}$, respectively. The cross-section of silicalite layer exhibits typical columnar grains with clear grain boundary [50]. In contrast, the grain boundary on the cross-section of ZSM-5 layer is not obvious.
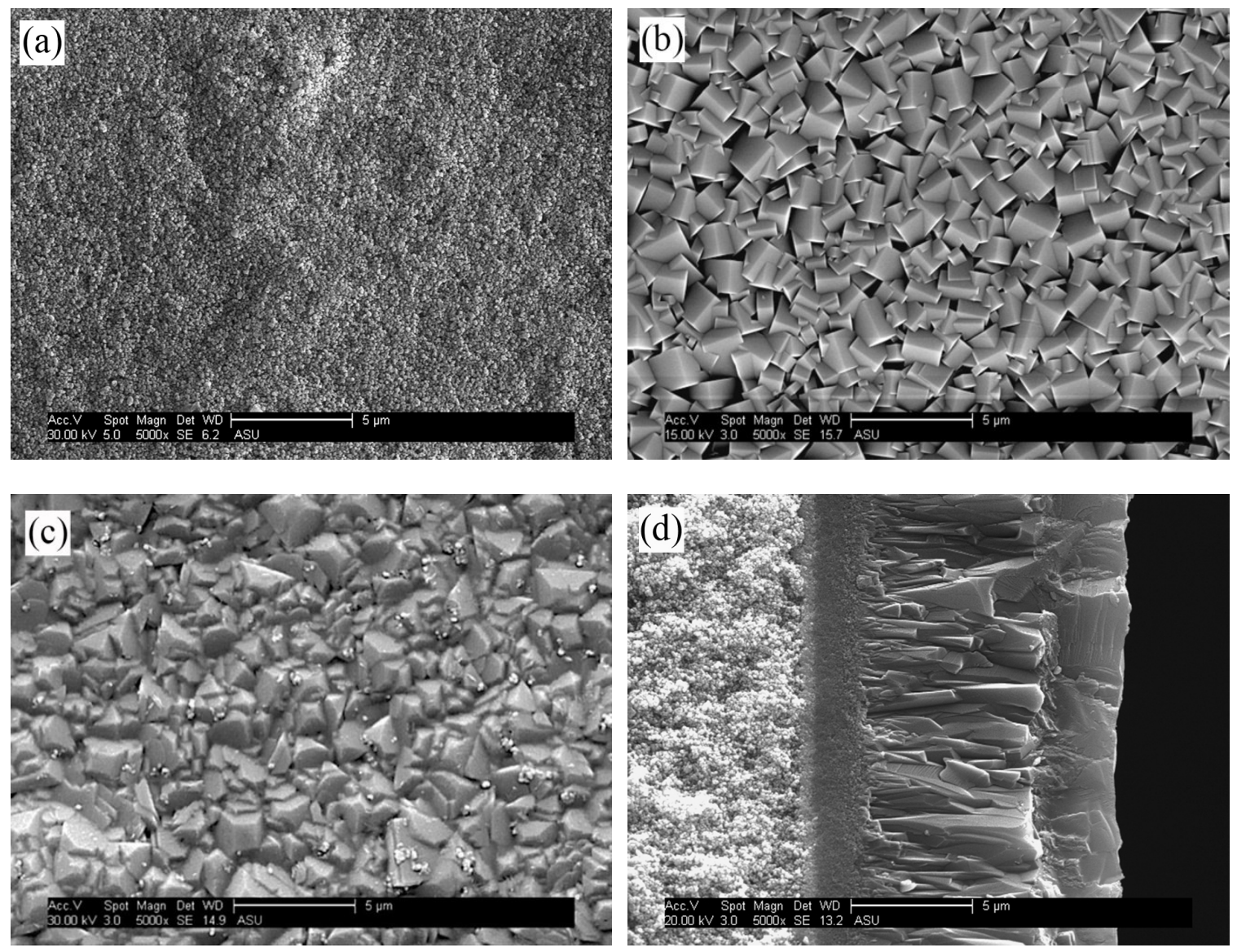

Figure 3 SEM images of (a) surface of YSZ modified tubular alumina support; (b) surface of 
silicalite layer; (c) surface of tubular ZSM-5/silicalite bilayer membrane; (d) cross section of tubular ZSM-5/silicalite bilayer membrane.

An on-stream CCD modification was used to reduce the zeolitic pore size and improve the $\mathrm{H}_{2} / \mathrm{CO}_{2}$ separation performance of the tubular ZSM-5/silicalite bilayer membrane. At room temperature, this membrane showed a $\mathrm{H}_{2} / \mathrm{CO}_{2}$ separation factor of 0.31 , indicating that the membrane was highly selective to $\mathrm{CO}_{2}$ at room temperature and the sealing system of the tubular membrane permeation cell worked well at room temperature [34]. The membrane was heated up to $450{ }^{\circ} \mathrm{C}$ for $\mathrm{CCD}$ modification. Figure 4 shows $\mathrm{CCD}$ modification results. At $450{ }^{\circ} \mathrm{C}$ before modification, the membrane shows $\mathrm{H}_{2}$ and $\mathrm{CO}_{2}$ permeance of $2.93 \times 10^{-7}$ and $7.5 \times 10^{-8}$ $\mathrm{mol} \cdot \mathrm{m}^{-2} \cdot \mathrm{s}^{-1} \cdot \mathrm{Pa}^{-1}$ with a $\mathrm{H}_{2} / \mathrm{CO}_{2}$ separation factor of 3.16 at $450{ }^{\circ} \mathrm{C}$. As the modification started, both $\mathrm{H}_{2}$ and $\mathrm{CO}_{2}$ gas permeance decreased significantly. Since the decrease of $\mathrm{CO}_{2}$ permeance reaches about $87 \%$ while the decrease of $\mathrm{H}_{2}$ permeance is around $34 \%$, the $\mathrm{H}_{2} / \mathrm{CO}_{2}$ separation factor increases as the modification continued. After the $\mathrm{CCD}$ modification, $\mathrm{H}_{2}$ and $\mathrm{CO}_{2}$ permeance are $1.94 \times 10^{-7}$ and $9.8 \times 10^{-9} \mathrm{~mol} \cdot \mathrm{m}^{-2} \cdot \mathrm{s}^{-1} \cdot \mathrm{Pa}^{-1}$, respectively, and the $\mathrm{H}_{2} / \mathrm{CO}_{2}$ separation factor reaches 16.01. Compared with the disk ZSM-5/silicalite bilayer membrane prepared in our previous work (with the $\mathrm{H}_{2}$ permeance of $1.28 \times 10^{-7} \mathrm{~mol} \cdot \mathrm{m}^{-2} \cdot \mathrm{s}^{-1} \cdot \mathrm{Pa}^{-1}$ and $\mathrm{H}_{2} / \mathrm{CO}_{2}$ separation factor of 25.3 after $\mathrm{CCD}$ modification at $450{ }^{\circ} \mathrm{C}$ ) [36], the $\mathrm{H}_{2}$ permeance of the tubular membrane is higher, however the $\mathrm{H}_{2} / \mathrm{CO}_{2}$ separation factor is lower. This may be attributed to small amount of intercrytalline defects in the tubular membrane or possible small leak in the graphite seals at the end of the tubes at high temperatures. 


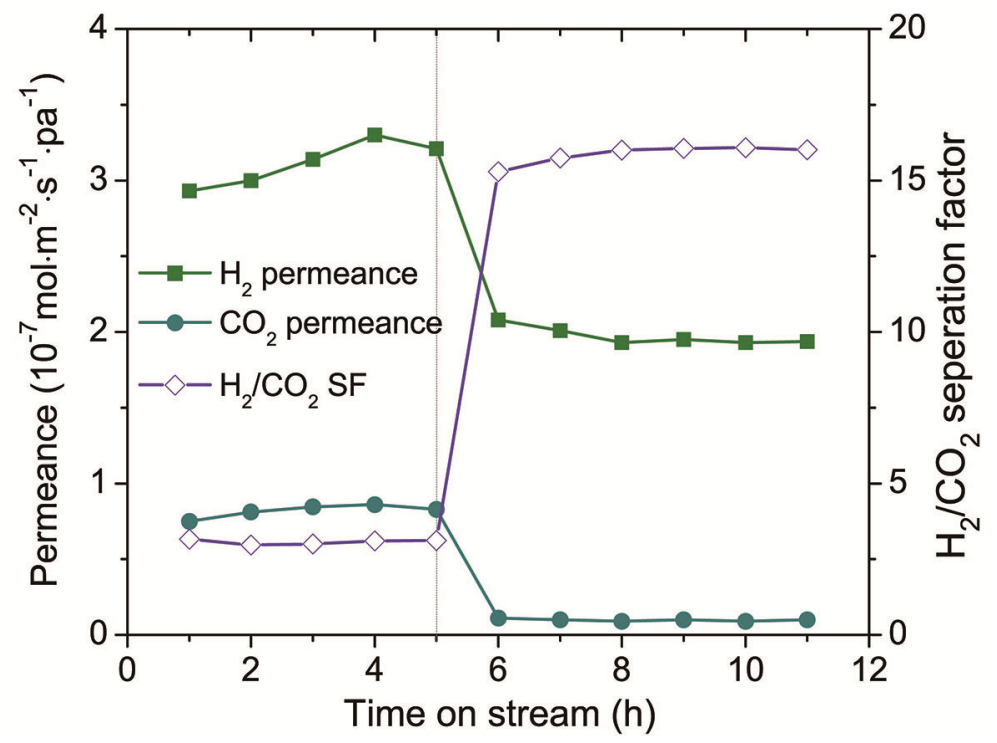

Figure 4 Variations of gas permeance and $\mathrm{H}_{2} / \mathrm{CO}_{2}$ separation factor during $\mathrm{CCD}$ modification of the tubular ZSM-5/silicalite bilayer membrane at $450{ }^{\circ} \mathrm{C}$.

4.2 WGS reaction in tubular MFI zeolite membrane reactors under atmospheric pressure

Figure 5 shows the $\mathrm{CO}$ conversion and $\mathrm{H}_{2}$ recovery of the ZSM-5/silicalite bilayer membrane reactor $(\mathrm{MR})$ as a function of reaction temperature. For comparison, the calculated $\mathrm{CO}$ conversion of the traditional reactor (TR) without $\mathrm{H}_{2}$ removal and the $\mathrm{CO}$ equilibrium conversion were also added. The $\mathrm{CO}$ conversion increases significantly with increasing temperature, while the $\mathrm{H}_{2}$ recovery shows a slight increase trend. At $550{ }^{\circ} \mathrm{C}$, the $\mathrm{CO}$ conversion reaches $88.0 \%$, which is close to the equilibrium conversion and higher than the conversion in TR $(84.5 \%)$. The $\mathrm{H}_{2}$ recovery is $16.4 \%$ at this temperature. These results indicate that the operation temperature is a key factor to control the reaction. Although the WGS is a weak exothermic reaction, relatively high operation temperature is benefit for obtaining high $\mathrm{CO}$ conversion. This is caused by the enhancement of kinetic with temperature [17]. Moreover, the $\mathrm{CO}$ conversion is lower than the equilibrium conversion, and therefore the limitation of the thermodynamic equilibrium is not obvious. Below $500{ }^{\circ} \mathrm{C}$, the $\mathrm{CO}$ conversion of the MR is very 
close to that in TR, indicating that the contribution of membrane to $\mathrm{CO}$ conversion is not obvious. In other words, compared with the $\mathrm{H}_{2}$ production rate, the $\mathrm{H}_{2}$ removal rate through the membrane is not high enough to shift the reaction equilibrium and promote the CO conversion. Therefore, the further improvement of the $\mathrm{H}_{2}$ permeation flux is desired.

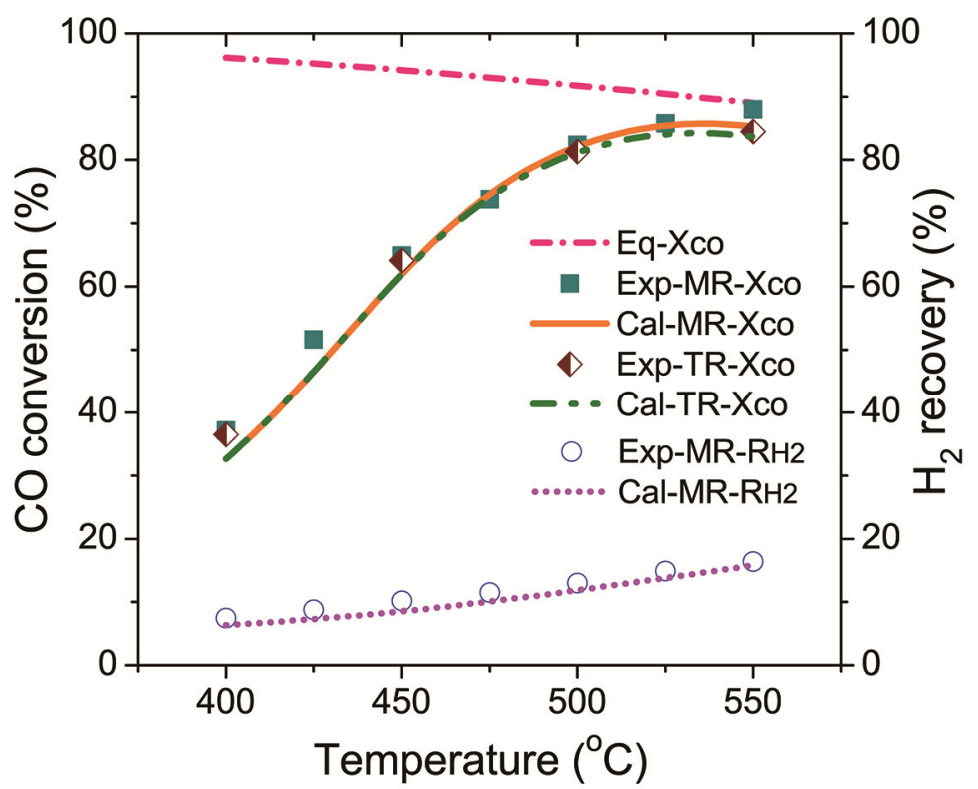

Figure 5 Effect of temperature on the $\mathrm{CO}$ conversion $\left(\operatorname{Exp}-M R-X_{C O}\right)$ and $\mathrm{H}_{2}$ recovery $\left(\operatorname{Exp}-M R-R_{H 2}\right)$ of the ZSM-5/silicalite bilayer membrane reactor (MR). $\mathrm{H}_{2} \mathrm{O} / \mathrm{CO}$ ratio is 3.0; GHSV is $72000 \mathrm{~h}^{-1}$ (CO flow rate of $30 \mathrm{ml} \cdot \mathrm{min}^{-1}$ ); Ar flow rate is $30 \mathrm{ml} \cdot \mathrm{min}^{-1}$; feed pressure is 1 atm. Eq-X $X_{C O}$ : equilibrium CO conversion; $C a l-M R-X_{C O}$ and $C a l-M R-R_{H 2}$ : calculated result of CO conversion and $\mathrm{H}_{2}$ recovery, respectively; Exp-TR-X $X_{C O}$ and Cal-TR-X $X_{C O}$ : Experimental and calculated results of $\mathrm{CO}$ conversion of traditional reactor (TR) under the identical conditions.

Figure 6 shows the experimental and modeling results of the $\mathrm{CO}$ conversion and $\mathrm{H}_{2}$ recovery of the ZSM-5/silicalite bilayer membrane reactor as a function of steam to $\mathrm{CO}\left(\mathrm{H}_{2} \mathrm{O} / \mathrm{CO}\right)$ ratio. With increasing the $\mathrm{H}_{2} \mathrm{O} / \mathrm{CO}$ ratio, the $\mathrm{CO}$ conversion increases while the $\mathrm{H}_{2}$ recovery shows a decrease trend. When the $\mathrm{H}_{2} \mathrm{O} / \mathrm{CO}$ ratio is 3.0 , the $\mathrm{CO}$ conversion reaches $82.4 \%$ and the $\mathrm{H}_{2}$ 
recovery is about $13.0 \%$. The enhancement of $\mathrm{CO}$ conversion is more significant at low $\mathrm{H}_{2} \mathrm{O} / \mathrm{CO}$ ratio of 1.0-2.0. However, further increase of $\mathrm{H}_{2} \mathrm{O} / \mathrm{CO}$ results in a relatively slow increase of $\mathrm{CO}$ conversion. The CO conversion is lower than the equilibrium conversion even the $\mathrm{H}_{2} \mathrm{O} / \mathrm{CO}$ ratio reached 3.0. These results are attributed to that high $\mathrm{H}_{2} \mathrm{O} / \mathrm{CO}$ ratio greatly increases the space velocity since the $\mathrm{CO}$ flow rate is fixed at $30 \mathrm{ml} \cdot \mathrm{min}^{-1}$. As is well known, high space velocity is unfavorable for both $\mathrm{CO}$ conversion and $\mathrm{H}_{2}$ recovery. In addition, excessive steam for the relatively high $\mathrm{H}_{2} \mathrm{O} / \mathrm{CO}$ ratio reduces the partial pressure of $\mathrm{H}_{2}$ in the reaction side, resulting in the low $\mathrm{H}_{2}$ permeation flux and low $\mathrm{H}_{2}$ recovery.

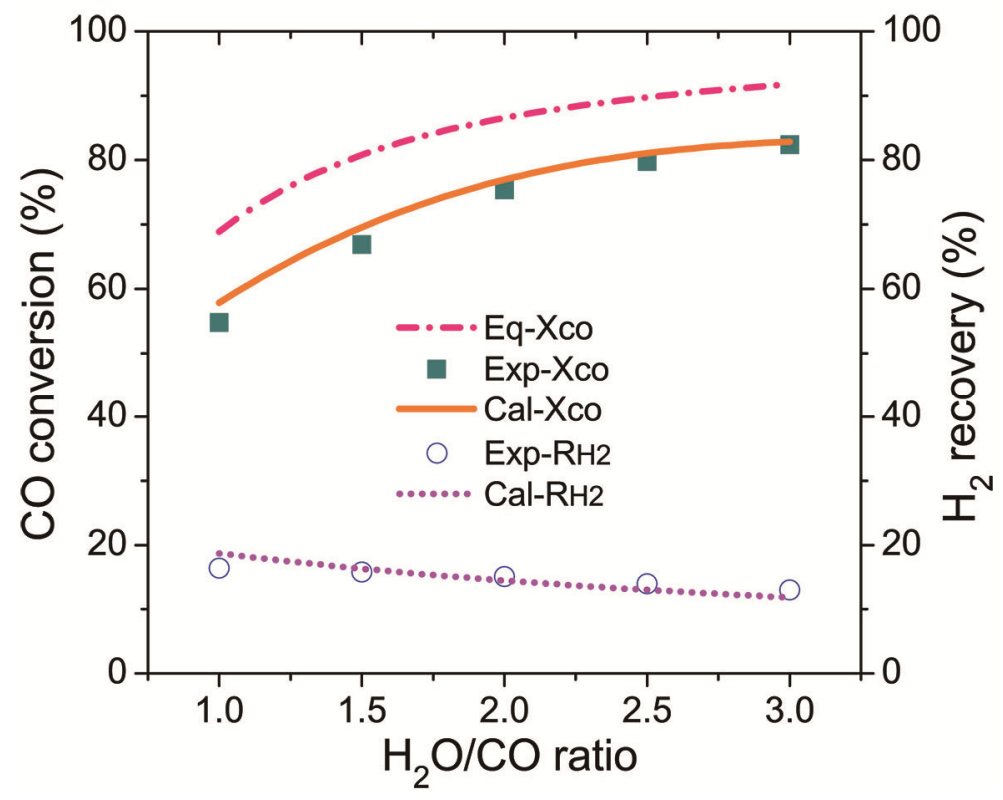

Figure 6 Effect of $\mathrm{H}_{2} \mathrm{O} / \mathrm{CO}$ ratio on the $\mathrm{CO}$ conversion $\left(\operatorname{Exp}-X_{C O}\right)$ and $\mathrm{H}_{2}$ recovery $\left(\operatorname{Exp}-R_{H 2}\right)$ of the ZSM-5/silicalite bilayer membrane reactor. Reaction temperature is $500{ }^{\circ} \mathrm{C}$; $\mathrm{CO}$ flow rate is $30 \mathrm{ml} \cdot \mathrm{min}^{-1}$; Ar flow rate is $30 \mathrm{ml} \cdot \mathrm{min}^{-1}$; feed pressure is $1 \mathrm{~atm} . E q-X_{C O}$ : equilibrium CO conversion; Cal- $X_{C O}$ and Cal- $R_{H 2}$ : calculated results of $\mathrm{CO}$ conversion and $\mathrm{H}_{2}$ recovery, respectively.

The effect of gas hourly space velocity (GHSV) on the WGS performance was also studied based on both experiment and model calculation. The GHSV increased from $48000 \mathrm{~h}^{-1}$ to $120000 \mathrm{~h}^{-1}$ as 
the $\mathrm{CO}$ feed flow rate increased from $20 \mathrm{ml} \cdot \mathrm{min}^{-1}$ to $50 \mathrm{ml} \cdot \mathrm{min}^{-1}$. Figure 7 shows the $\mathrm{CO}$ conversion and $\mathrm{H}_{2}$ recovery of the ZSM-5/silicalite bilayer membrane reactor as a function of GHSV. Both $\mathrm{CO}$ conversion and $\mathrm{H}_{2}$ recovery decrease with increasing GHSV. When the GHSV is $48000 \mathrm{~h}^{-1}$, the CO conversion is $90.3 \%$ and close to the equilibrium conversion $(91.7 \%)$ at 500 ${ }^{\circ} \mathrm{C}$, and the $\mathrm{H}_{2}$ recovery is $18.6 \%$. However, the higher GHSV reduces the residence time for WGS reaction and the reaction on the catalyst seems not quick enough to convert so much $\mathrm{CO}$, leading to the decrease of CO conversion. Additionally, the higher GHSV has adverse effect on $\mathrm{H}_{2}$ removal through the membrane because the $\mathrm{H}_{2}$ transport rate is not very high under the atmospheric pressure (feed side). Moreover, too much unreacted $\mathrm{CO}$ and steam in the feed greatly reduces the $\mathrm{H}_{2}$ partial pressure, leading to the low $\mathrm{H}_{2}$ permeation flux and decrease of $\mathrm{H}_{2}$ recovery. Therefore, the role of zeolite membrane in the membrane reactor is also restrained at high GHSV.

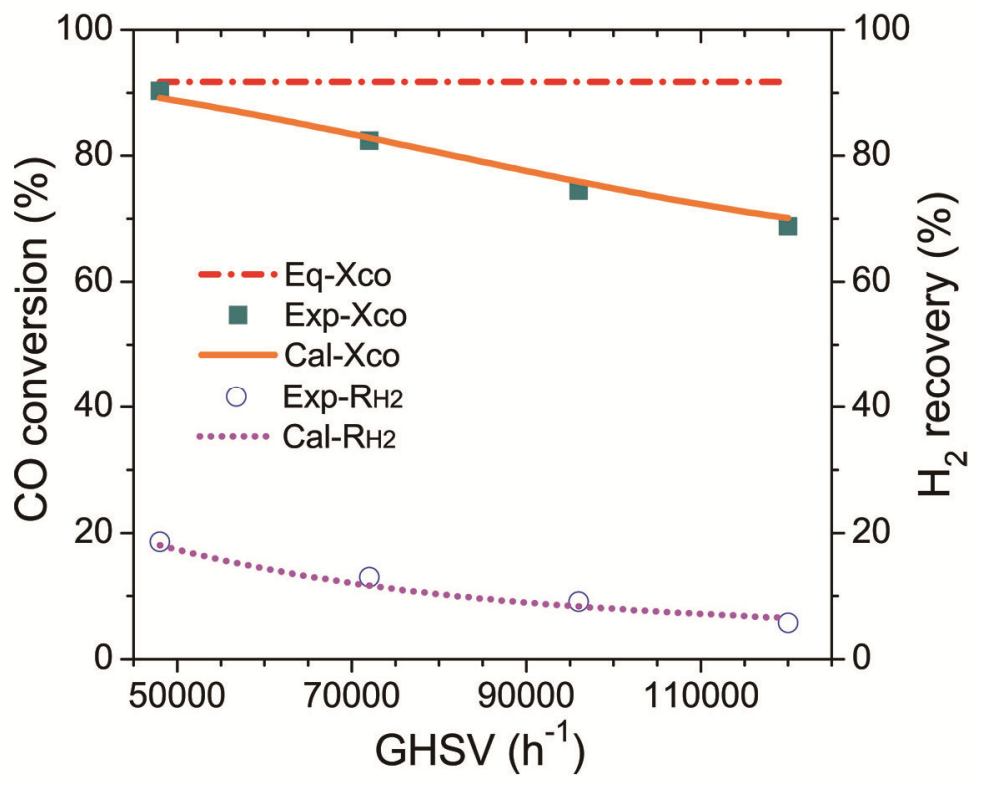

Figure 7 Effect of GHSV on the CO conversion $\left(E x p-X_{C O}\right)$ and $\mathrm{H}_{2}$ recovery $\left(E x p-R_{H 2}\right)$ of the ZSM-5/silicalite bilayer membrane reactor. Reaction temperature is $500{ }^{\circ} \mathrm{C} ; \mathrm{H}_{2} \mathrm{O} / \mathrm{CO}$ ratio is 3.0 ; Ar flow rate is $30 \mathrm{ml} \cdot \mathrm{min}^{-1}$; feed pressure is $1 \mathrm{~atm} . E q-X_{C O}$ : equilibrium CO conversion; Cal- $X_{C O}$ and Cal- $R_{H 2}$ : calculated results of $\mathrm{CO}$ conversion and $\mathrm{H}_{2}$ recovery, respectively. 
Figure 8 shows the $\mathrm{CO}$ conversion and $\mathrm{H}_{2}$ recovery of the ZSM-5/silicalite bilayer membrane reactor as a function of sweep gas (Ar) flow rate. In general, the increase of sweep gas flow rate will effectively reduce the partial pressure of $\mathrm{H}_{2}$ at the permeate side and improve the $\mathrm{H}_{2}$ permeation flux, resulting in increase of both $\mathrm{CO}$ conversion and $\mathrm{H}_{2}$ recovery. From Figure 8, however, both $\mathrm{CO}$ conversion and $\mathrm{H}_{2}$ recovery show a very slight increase with increasing $\mathrm{Ar}$ flow rate. A possible explanation is that the high Ar flow rate really reduces the $\mathrm{H}_{2}$ partial pressure, but also significantly increase the Ar partial pressure at the permeate side, resulting in a permeation of Ar through the membrane in reverse direction. This reverse diffusion of Ar may reduce the $\mathrm{H}_{2}$ permeation through the zeolite channels. Therefore, the increase of $\mathrm{CO}$ conversion and $\mathrm{H}_{2}$ recovery is not obvious with the increase of Ar flow rate. The model results further confirm that the influence of Ar flow rate on the WGS performance is limited. Tang et al. [17] also stated that the counter-diffusion of sweep gas through the membrane might inhibit the $\mathrm{H}_{2}$ transfer in the zeolite channels.

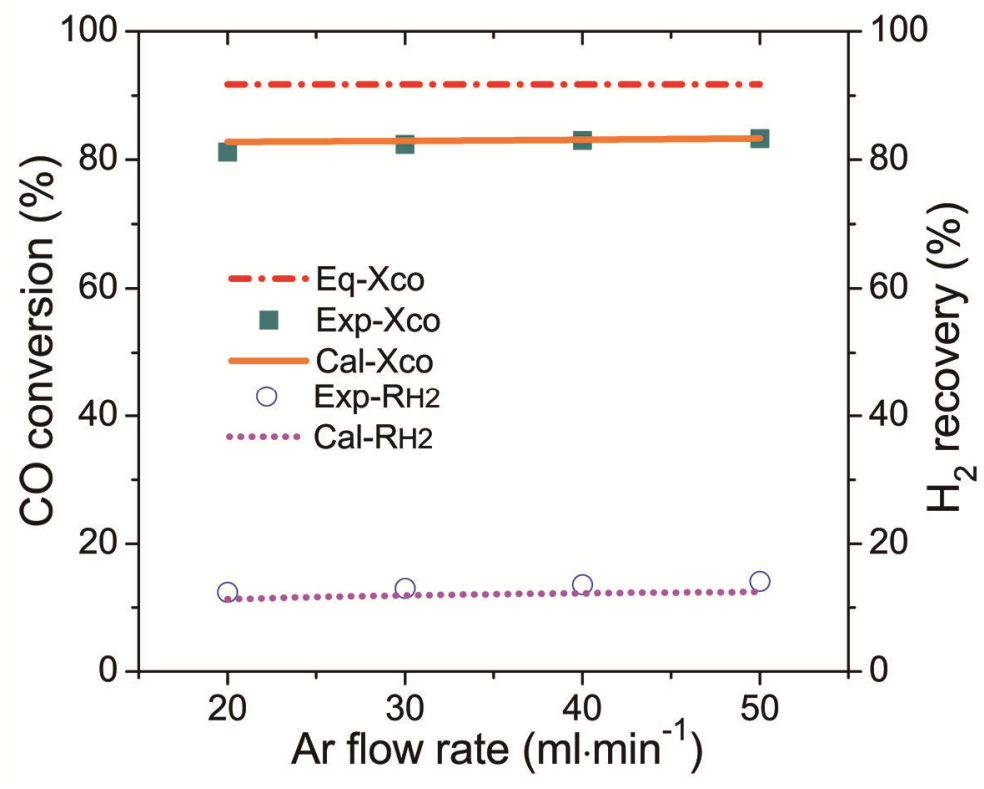

Figure 8 Effect of sweep gas (Ar) flow rate on the $\mathrm{CO}$ conversion $\left(\operatorname{Exp}-X_{C O}\right)$ and $\mathrm{H}_{2}$ recovery $\left(\operatorname{Exp}-R_{H 2}\right)$ of the ZSM-5/silicalite bilayer membrane reactor. Reaction temperature is $500{ }^{\circ} \mathrm{C}$; $\mathrm{H}_{2} \mathrm{O} / \mathrm{CO}$ ratio is 3.0; GHSV is $72000 \mathrm{~h}^{-1}$ ( $\mathrm{CO}$ flow rate of $30 \mathrm{ml} \cdot \mathrm{min}^{-1}$ ); feed pressure is 1 atm. $E q-X_{C O}$ : equilibrium $\mathrm{CO}$ conversion; $\mathrm{Cal}-\mathrm{X}_{\mathrm{CO}}$ and $\mathrm{Cal}-\mathrm{R}_{\mathrm{H} 2}$ : calculated results of $\mathrm{CO}$ conversion 
and $\mathrm{H}_{2}$ recovery, respectively.

Table 2 listed the $\mathrm{H}_{2}$ separation and WGS reaction performance of different MFI-type zeolite membranes. It is really difficult to compare the WGS reaction performance of these membranes in Table 2 due to the different membrane types, membrane preparations and WGS reaction operating conditions. However, it can be found that the comprehensive performance of our ZSM-5/silicalite bilayer membrane is comparable with other MFI-type zeolite membranes. From Table 2, beside the membrane separation performance, the optimum reaction conditions are also crucial to obtain high reaction performance.

Table 2 Hydrogen separation and WGS reaction performance of different MFI-type zeolite membranes.

\begin{tabular}{|c|c|c|c|c|c|c|c|c|c|}
\hline \multirow[b]{2}{*}{$\begin{array}{l}\text { Membrane } \\
\text { Type }\end{array}$} & \multicolumn{2}{|c|}{ Separation Performance } & \multicolumn{6}{|c|}{ WGC Reaction Performance } & \multirow[b]{2}{*}{ Ref. } \\
\hline & $\begin{array}{c}\text { Temperature } \\
\left({ }^{\circ} \mathrm{C}\right)\end{array}$ & $\begin{array}{c}\mathrm{H}_{2} / \mathrm{CO}_{2} \\
\text { Separation } \\
\text { Factor } \\
\end{array}$ & $\begin{array}{c}\text { Temperature } \\
\left({ }^{\circ} \mathrm{C}\right)\end{array}$ & $\begin{array}{c}\text { Feed } \\
\text { Pressure } \\
\text { (atm) }\end{array}$ & $\begin{array}{c}\text { Space } \\
\text { Velocity } \\
\left(\mathrm{h}^{-1}\right) \\
\end{array}$ & $\begin{array}{l}\text { Steam } \\
\text { to } \mathrm{CO} \\
\text { Ratio }\end{array}$ & $\begin{array}{l}\text { Xco } \\
(\%)\end{array}$ & $\begin{array}{l}\mathrm{R}_{\mathrm{H} 2} \\
(\%)\end{array}$ & \\
\hline disk & 450 & 10.9 & 550 & 2 & 60000 & 3.5 & 91.6 & 32.2 & {$[18]$} \\
\hline disk & 550 & 11.3 & 550 & 6 & 60000 & 3.5 & 93.6 & 41 & {$[18]$} \\
\hline \multirow{2}{*}{ disk } & \multirow{2}{*}{500} & \multirow{2}{*}{30.7} & 550 & 2 & 60000 & 3.5 & 92.7 & - & [19] \\
\hline & & & 550 & 6 & 7500 & 3.5 & 98.5 & 73.2 & [19] \\
\hline disk & 500 & 42.6 & 300 & 1 & 1500 & 1.25 & 95.4 & 19.7 & [20] \\
\hline disk & 450 & 25.3 & 500 & 1 & 60000 & 3.0 & 84 & 23.2 & [21] \\
\hline tube & 450 & 43.2 & 550 & 1 & 60000 & 1.0 & 81.7 & - & [17] \\
\hline \multirow[t]{2}{*}{ tube } & 550 & 45.1 & 550 & 1 & 60000 & 3.5 & 94.0 & 30.4 & [17] \\
\hline & & & 500 & 1 & 48000 & 3.0 & 90.3 & 18.6 & This work \\
\hline \multirow[t]{2}{*}{ tube } & 450 & 16.0 & 550 & 1 & 72000 & 3.0 & 88.0 & 16.4 & This work \\
\hline & & & 500 & 5 & 72000 & 3.0 & 89.8 & 34.7 & This work \\
\hline
\end{tabular}

From Figures 6-8, it is worth noting that the modeling results agree well with the experimental data, indicating the validity of the values for the parameters used in the model. In other words, our model is highly reliable for the prediction of WGS reaction performance of the ZSM-5/silicalite bilayer membrane reactor. 
4.3 High pressure WGS reaction in tubular MFI zeolite membrane reactors

Since there is no change in the volume from reactants to products, the WGS reaction itself will not be affected by pressure. In the ZSM-5/silicalite bilayer membrane reactor, however, high operation pressure at the reaction side (feed side) is beneficial for the transport of the produced $\mathrm{H}_{2}$ through the membrane, resulting in the shift of the reaction equilibrium toward $\mathrm{H}_{2}$ production, promoting the $\mathrm{CO}$ conversion. Therefore, feed pressure is an important factor for WGS reaction in membrane reactor with $\mathrm{H}_{2}$ or $\mathrm{CO}_{2}$ removal $[8,18]$. The effect of feed pressure on the WGS reaction performance was studied and the results are shown in Figure 9a. Considering the safe operation of the experiments in the Lab, the feed pressure increased up to $5 \mathrm{~atm}$. As the pressure increases from 1 to 5 atm, $\mathrm{CO}$ conversion increases from $82.4 \%$ to $89.8 \%$ and the $\mathrm{H}_{2}$ recovery increases significantly from $11.6 \%$ to $28.5 \%$. This result shows the great contribution of the membrane to $\mathrm{CO}$ conversion. In addition, high operation pressure promotes the $\mathrm{H}_{2}$ permeation through the membrane, resulting in high $\mathrm{H}_{2}$ recovery. Therefore, feed pressure is also a key factor to control the reaction process. In typical practical process, the pressure of WGS reaction is higher than 30 atm [2], such high pressure is very suitable for the application of membrane reactor to obtain high reaction performance.

From Figure 9a, the modeling results can well represent the experiment data, further confirming the reliability of our model. Therefore, we predicted the WGS reaction performance in a wide pressure range (from 5 to $30 \mathrm{~atm}$ ) based on the model calculation. As shown in Figure 9b, the $\mathrm{CO}$ conversion and $\mathrm{H}_{2}$ recovery are $93.1 \%$ (higher than the equilibrium conversion) and $57.7 \%$, respectively, when the feed pressure is 10 atm. More excitingly, they reach $96.8 \%$ and $82.0 \%$, respectively, at 20 atm, and 98.8\% and 93.3\%, respectively, at 30 atm. From Figure 9b, the high $\mathrm{H}_{2}$ transport rate caused by the high feed pressure greatly shifts the reaction equilibrium, and a strong enhancement of membrane reactor performance is achieved. 
(a)

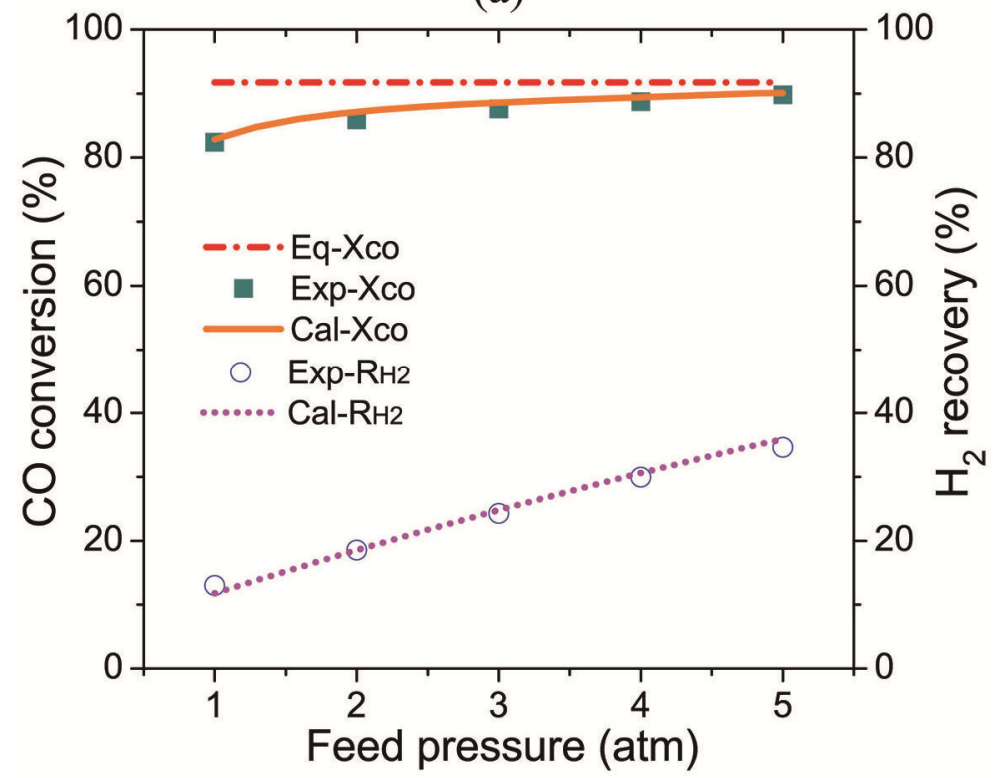

(b)

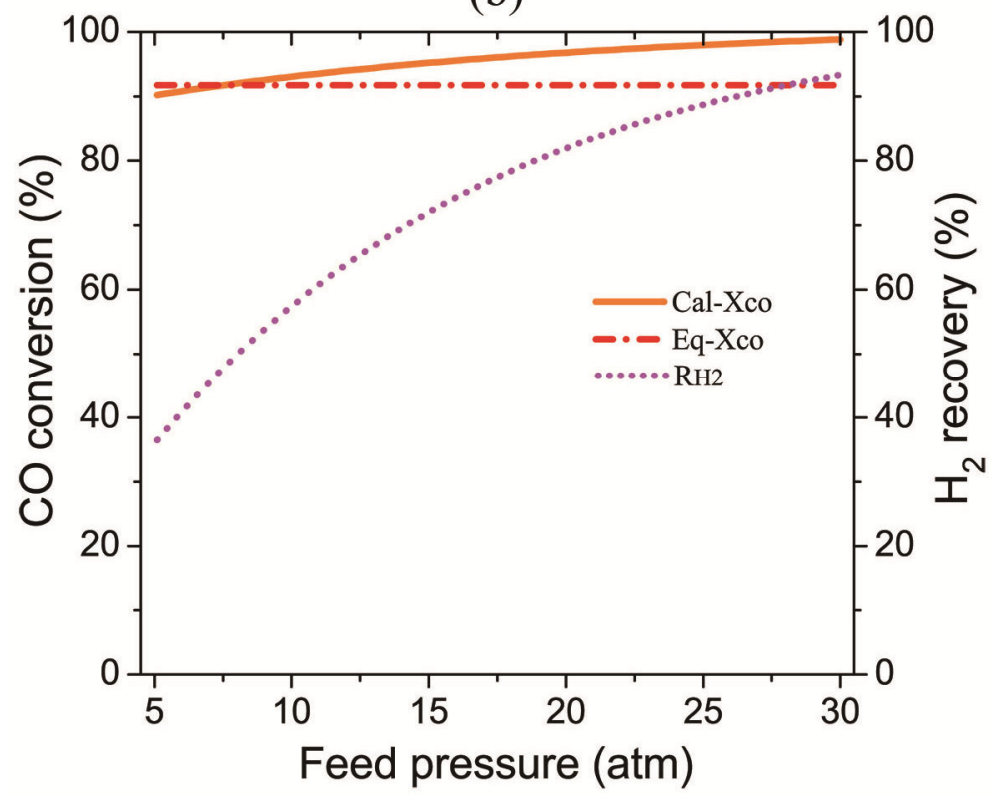

Figure 9 Effect of feed pressure on the $\mathrm{CO}$ conversion $\left(\operatorname{Exp}-X_{C O}\right)$ and $\mathrm{H}_{2}$ recovery $\left(\operatorname{Exp}-R_{H 2}\right)$ of the ZSM-5/silicalite bilayer membrane reactor: (a) experiment and modeling results from 1 to 5 atm; (b) modeling results from 5 to $20 \mathrm{~atm}$. Reaction temperature is $500{ }^{\circ} \mathrm{C} ; \mathrm{H}_{2} \mathrm{O} / \mathrm{CO}$ ratio is 3.0 ; GHSV is $72000 \mathrm{~h}^{-1}$ (CO flow rate of $30 \mathrm{ml} \cdot \mathrm{min}^{-1}$ ); Ar flow rate is $30 \mathrm{ml} \cdot \mathrm{min}^{-1} . E q-X_{C O}$ : equilibrium $\mathrm{CO}$ conversion; $\mathrm{Cal}-\mathrm{X}_{\mathrm{CO}}$ and $\mathrm{Cal}-\mathrm{R}_{\mathrm{H} 2}$ : calculated results of $\mathrm{CO}$ conversion and $\mathrm{H}_{2}$ recovery, respectively. 
To further evaluate the high pressure WGS performance, the effects of temperature and $\mathrm{H}_{2} \mathrm{O} / \mathrm{CO}$ ratio on CO conversion was studied at 10, 20 and 30 atm. As shown in Figure 10a, the CO conversion increases significantly with temperature before $460{ }^{\circ} \mathrm{C}$, however, further enhancement of $\mathrm{CO}$ conversion is difficult by adjusting the temperature. From the WGS reaction kinetic, reaction rate ( $\mathrm{CO}$ conversion) increases with increasing the temperature [17]. However, the $\mathrm{CO}$ conversion is higher than the equilibrium conversion therefore the limitation of $\mathrm{CO}$ conversion by the thermodynamic equilibrium is obvious when further increase the temperature. Moreover, the $\mathrm{H}_{2}$ transport rate has reached a high level under high feed pressure. Further greatly enhancing the $\mathrm{H}_{2}$ transport rate and strongly shifting the reaction equilibrium by increasing the temperature (from $460{ }^{\circ} \mathrm{C}$ to $550{ }^{\circ} \mathrm{C}$ ) may be difficult. Above $460{ }^{\circ} \mathrm{C}$, the $\mathrm{CO}$ conversion increases with increasing $\mathrm{H}_{2} \mathrm{O} / \mathrm{CO}$ ratio, especially from 1.0 to 2.5 . Under the pressure of $20 \mathrm{~atm}$ (Figure 10b), the $\mathrm{CO}$ conversion reaches about $97 \%$ with the $\mathrm{H}_{2} \mathrm{O} / \mathrm{CO}$ ratio above 2.0 and temperature above $440{ }^{\circ} \mathrm{C}$. In contrast, under the pressure of $30 \mathrm{~atm}$ (Figure 10c), an extremely high $\mathrm{CO}$ conversion (close to $99 \%$ ) can be obtained at a wider range of temperature and $\mathrm{H}_{2} \mathrm{O} / \mathrm{CO}$ ratio. Therefore, to achieve a high CO conversion (>95\%) is possible under high feed pressure by controlling the temperature and $\mathrm{H}_{2} \mathrm{O} / \mathrm{CO}$ ratio. 

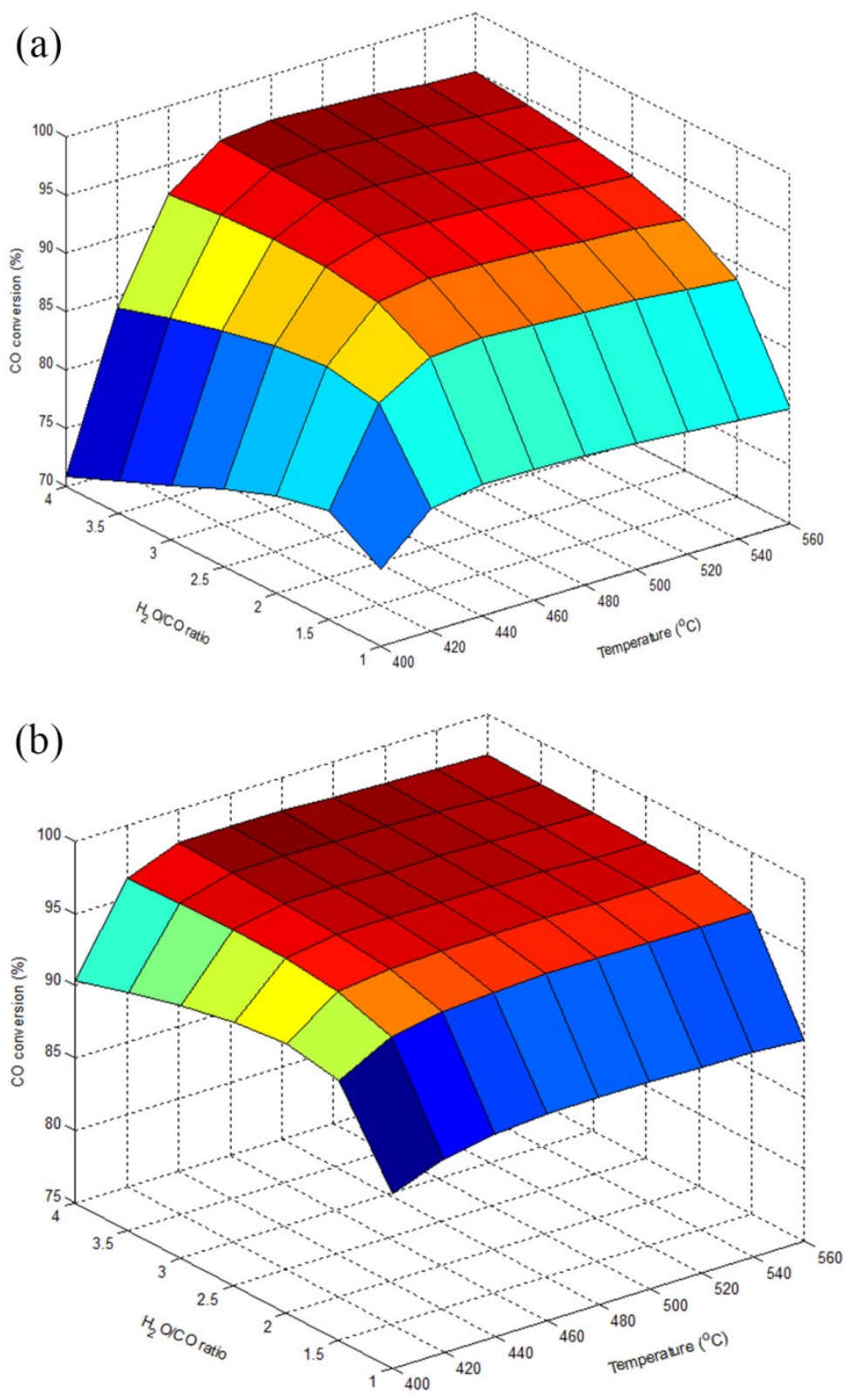


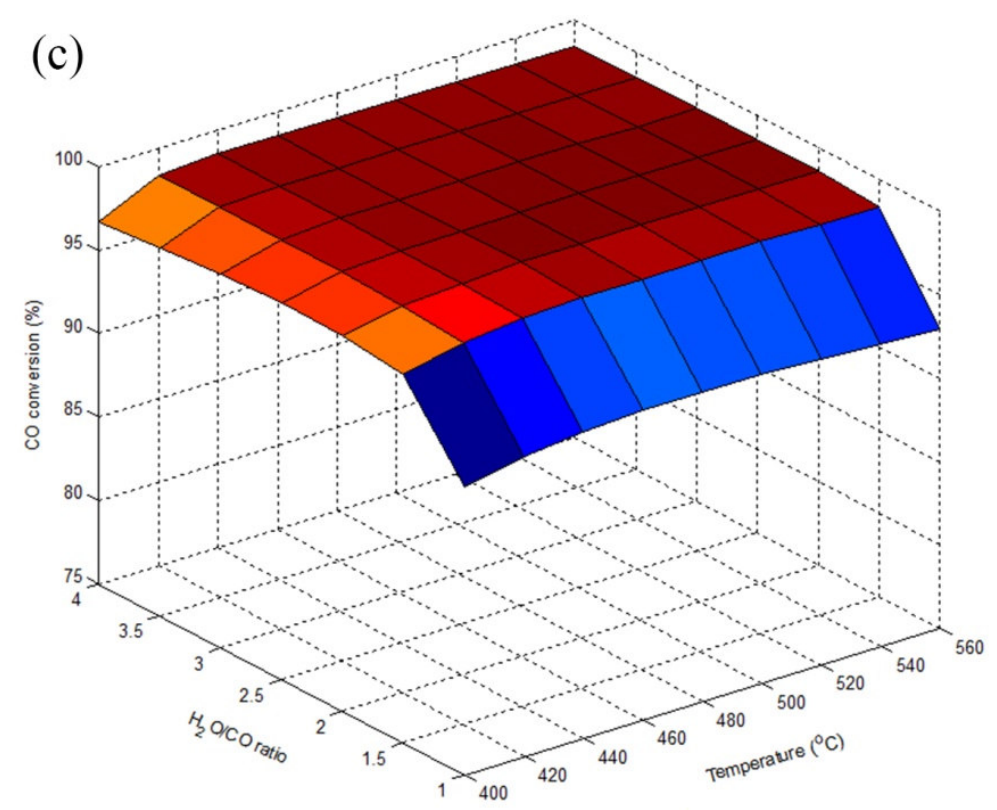

Figure 10 Calculated results of $\mathrm{CO}$ conversion as a function of $\mathrm{H}_{2} \mathrm{O} / \mathrm{CO}$ ratio and temperature in the membrane reactor with the feed pressure of (a) $10 \mathrm{~atm}$; (b) $20 \mathrm{~atm}$; (c) $30 \mathrm{~atm}$. GHSV is $72000 \mathrm{~h}^{-1}$ (CO flow rate of $30 \mathrm{ml} \cdot \mathrm{min}^{-1}$ ); Ar flow rate is $30 \mathrm{ml} \cdot \mathrm{min}^{-1}$.

\subsection{Optimization of operation condition}

The high reliability of the model allows us to further optimize the operation process of the WGS membrane reactor and to achieve both high $\mathrm{CO}$ conversion ( $>95 \%)$ and $\mathrm{H}_{2}$ recovery $(>90 \%)$. From sections 4.2 and 4.3, temperature, steam to $\mathrm{CO}$ ratio, space velocity, and pressure are key factors that affect the WGS reaction performance. Therefore, the optimization was focused mainly on these factors. In addition, the match between the GHSV and the WGS reaction rate, and match between the $\mathrm{H}_{2}$ production rate from WGS reaction and the $\mathrm{H}_{2}$ removal rate through the zeolite membrane are also considered.

To obtain a relatively high $\mathrm{H}_{2}$ recovery, the feed pressure was fixed at 20 and 30 atm, respectively. The $\mathrm{H}_{2} \mathrm{O} / \mathrm{CO}$ ratio was fixed at 3.0. Then, the effects of temperature and GHSV on the $\mathrm{CO}$ conversion and $\mathrm{H}_{2}$ recovery were analyzed. As shown in Figure 11a, above $420{ }^{\circ} \mathrm{C}$, the 
effect of temperature on the $\mathrm{CO}$ conversion (higher than 95\%) is not obvious. However, the $\mathrm{H}_{2}$ recovery increases significantly with temperature. Both $\mathrm{CO}$ conversion and $\mathrm{H}_{2}$ recovery are greatly dependent on the GHSV. At $550{ }^{\circ} \mathrm{C}, \mathrm{H}_{2}$ recovery can reach $90 \%$ when the GHSV is relatively low $\left(\leq 60000 \mathrm{~h}^{-1}\right)$. When the feed pressure and GHSV were fixed at 20 atm and 60000 $\mathrm{h}^{-1}$, respectively, the effects of temperature and $\mathrm{H}_{2} \mathrm{O} / \mathrm{CO}$ ratio on the $\mathrm{CO}$ conversion were further evaluated. As show in Figure 12a, a very high CO conversion (close to 98\%) is achieved with the temperature above $440{ }^{\circ} \mathrm{C}$ and $\mathrm{H}_{2} \mathrm{O} / \mathrm{CO}$ ratio higher than 2.0.

(a)

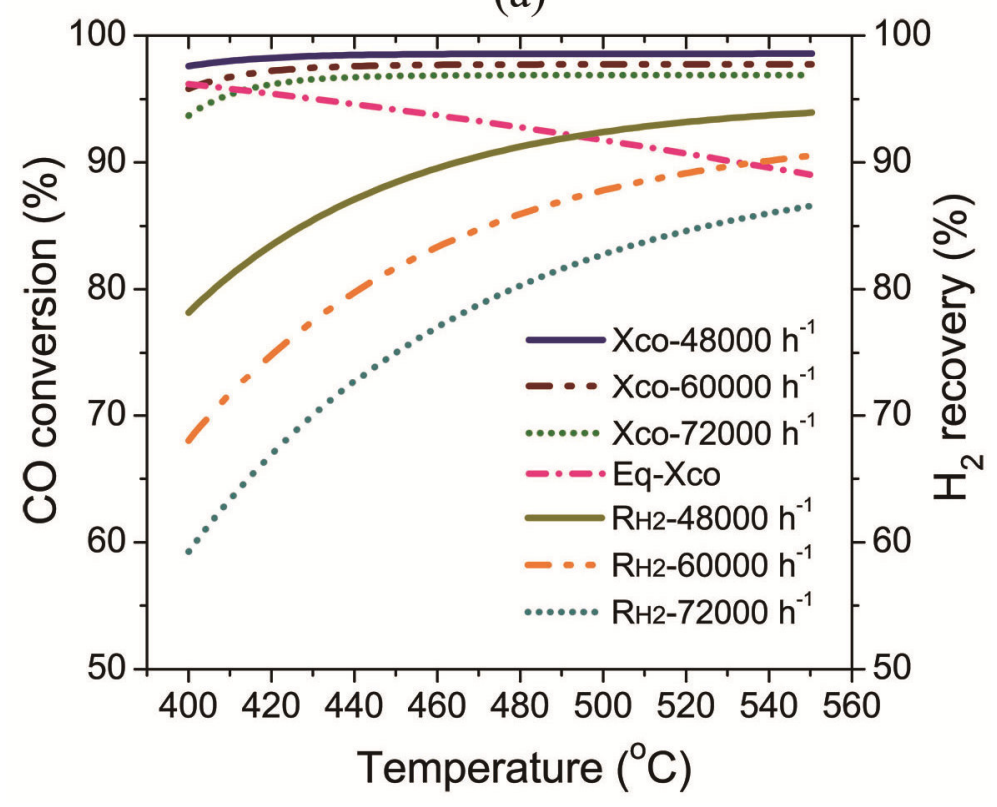


(b)

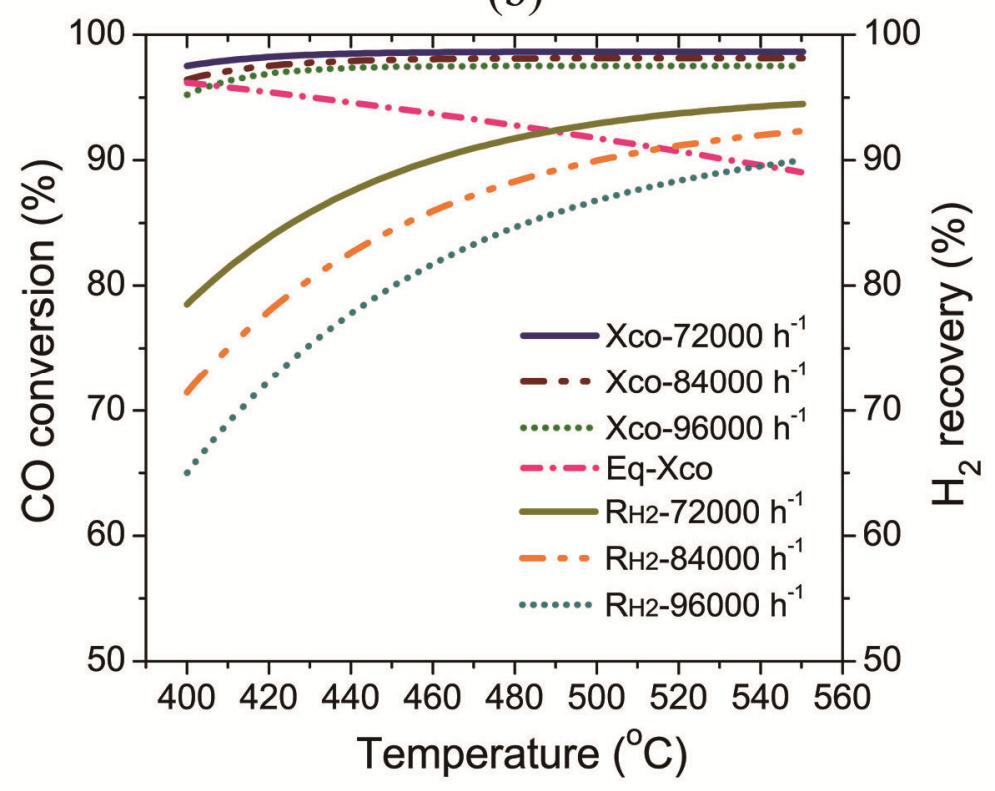

Figure 11 Calculated results of $\mathrm{CO}$ conversion and $\mathrm{H}_{2}$ recovery as function of temperature and GHSV in the membrane reactor with the feed pressure of (a) $20 \mathrm{~atm}$; (b) $30 \mathrm{~atm} . \mathrm{H}_{2} \mathrm{O} / \mathrm{CO}$ ratio is 3.0; Ar flow rate is $30 \mathrm{ml} \cdot \mathrm{min}^{-1} ; E q-X_{C O}$ : equilibrium $\mathrm{CO}$ conversion.

Further increase of the pressure to 30 atm, similar results can be found, as shown in Figure 11b. Although higher GHSV (from 72000 to $96000 \mathrm{~h}^{-1}$ ) were used, the high CO conversion (>95\%) could be obtained. This is attributed to the rapid $\mathrm{H}_{2}$ removal through the membrane under the high feed pressure, and greatly shifting the reaction equilibrium. At $550{ }^{\circ} \mathrm{C}, \mathrm{H}_{2}$ recovery can reach $90 \%$ even with high GHSV of $96000 \mathrm{~h}^{-1}$. When the feed pressure and GHSV were fixed at $30 \mathrm{~atm}$ and $84000 \mathrm{~h}^{-1}$, respectively, the effects of temperature and $\mathrm{H}_{2} \mathrm{O} / \mathrm{CO}$ ratio on the $\mathrm{CO}$ conversion were evaluated, as show in Figure 12b. Above $440{ }^{\circ} \mathrm{C}$ with the $\mathrm{H}_{2} \mathrm{O} / \mathrm{CO}$ ratio of 2.0-4.0, the change of $\mathrm{CO}$ conversion seems not obvious. 

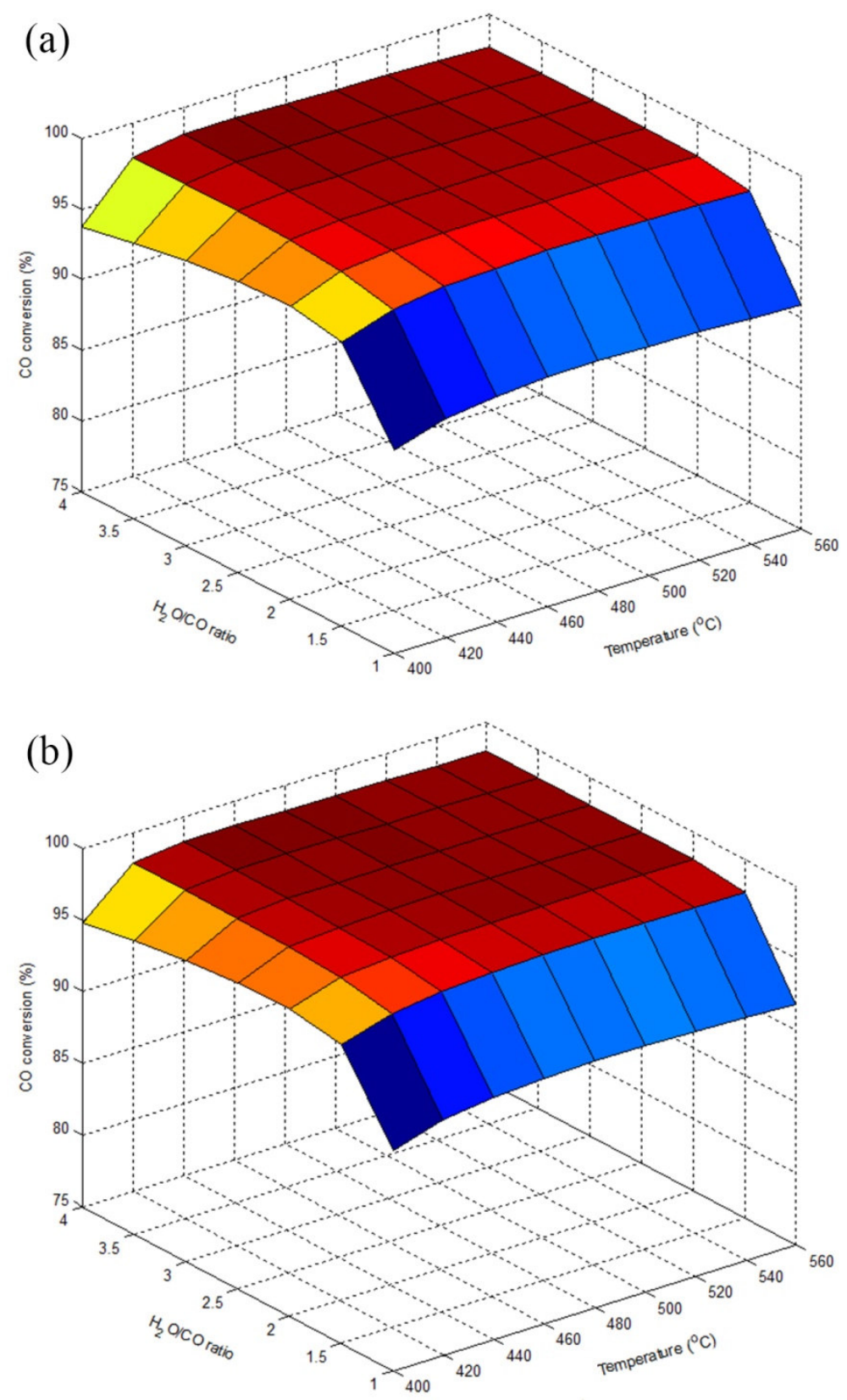

Figure 12 Calculated results of $\mathrm{CO}$ conversion as a function of $\mathrm{H}_{2} \mathrm{O} / \mathrm{CO}$ ratio and temperature in the membrane reactor. Ar flow rate is $30 \mathrm{ml} \cdot \mathrm{min}^{-1}$. (a) GHSV is $60000 \mathrm{~h}^{-1}$ (CO flow rate of 25 $\mathrm{ml} \cdot \mathrm{min}^{-1}$ ); feed pressure is $20 \mathrm{~atm}$; (b) GHSV is $84000 \mathrm{~h}^{-1}\left(\mathrm{CO}\right.$ flow rate of $\left.35 \mathrm{ml} \cdot \mathrm{min}^{-1}\right)$; feed pressure is $30 \mathrm{~atm}$.

From the modeling work, when the feed pressure is higher than $10 \mathrm{~atm}$, the reaction equilibrium 
limitation can be easily broken by the rapid removal of $\mathrm{H}_{2}$ through the membrane. High $\mathrm{CO}$ conversion $(>95 \%)$ could be achieved relatively easily in the membrane reactor operated under high feed pressure (above 20 atm). Considering both $\mathrm{CO}$ conversion and $\mathrm{H}_{2}$ recovery, the $\mathrm{H}_{2} \mathrm{O} / \mathrm{CO}$ ratio of 2.0 is appropriate. In contrast, it is rather difficult to achieve high $\mathrm{H}_{2}$ recovery $(>90 \%)$. Therefore, a relatively high temperature such as $550{ }^{\circ} \mathrm{C}$ is required. The match between the $\mathrm{H}_{2}$ production rate from WGS reaction and the $\mathrm{H}_{2}$ removal rate through the zeolite membrane is crucial. Accordingly, not only suitable feed pressure and temperature, but also appropriate GHSV are required. Considering that only very active catalysts can operate at the GHSV above $40000 \mathrm{~h}^{-1}$ [2], the appropriate GHSV of the zeolite membrane may be below $60000 \mathrm{~h}^{-1}$ except that the reaction was operated under a high pressure (around 30 atm).

\section{Conclusions}

MDES modified tubular ZSM-5/silicalite bilayer membrane exhibits high $\mathrm{H}_{2}$ permeance and moderate $\mathrm{H}_{2} / \mathrm{CO}_{2}$ separation factor. The experimental and modeling studies demonstrated that this membrane can be used as WGS membrane reactor to effectively improve the WGS reaction performance. Temperature, $\mathrm{H}_{2} \mathrm{O} / \mathrm{CO}$ ratio, GHSV and feed pressure are proved as key factors that affect the reaction performance in the membrane reactor. To achieve high $\mathrm{CO}$ conversion and $\mathrm{H}_{2}$ recovery, the reactor should be operated at high temperature and under high feed pressure. The high temperature results in the enhanced reaction kinetic. Both high temperature and high pressure are beneficial for the rapid $\mathrm{H}_{2}$ removal through the membrane, leading to the shift of reaction equilibrium toward $\mathrm{H}_{2}$ production, resulting in the enhancement of $\mathrm{CO}$ conversion and $\mathrm{H}_{2}$ recovery. Appropriate $\mathrm{H}_{2} \mathrm{O} / \mathrm{CO}$ ratio (2.0 ) and GHSV $\left(\sim 60000 \mathrm{~h}^{-1}\right)$ are also crucial to obtain high reaction performance. Although high $\mathrm{H}_{2} \mathrm{O} / \mathrm{CO}$ ratio means high $\mathrm{CO}$ conversion, it is unfavorable for $\mathrm{H}_{2}$ recovery. Relatively low GHSV would be advantage to CO conversion. Based on the modeling prediction results, it is possible to achieve both high CO conversion (>95\%) and $\mathrm{H}_{2}$ recovery $(>90 \%)$ in the zeolite membrane reactor. This work demonstrates that MFI-type zeolite membrane reactors have high potential for practical applications in WGS reaction 
process.

\section{Acknowledgement}

The authors would like to acknowledge the support of the U. S. Department of Energy (DE-PS36-03GO93007) for this project. We would also like to acknowledge Prof. Panagiotis Smirniotis at University of Cincinnati for providing the catalyst used for water gas shift reaction in this work.

\section{References}

[1] K. Polychronopoulou, C.M. Kalamaras, A.M. Efstathiou, Ceria-based materials for hydrogen production via hydrocarbon steam reforming and water-gas shift reactions, Recent Pat. Mater. Sci. 4 (2011) 122-145.

[2] C. Ratnasamy, J. Wagner, Water gas shift catalysis, Catal. Rev. 51 (2009) 325-440.

[3] S. Smart, C.X.C. Lin, L. Ding, K. Thambimuthub, J.C.D. da Costa, Ceramic membranes for gas processing in coal gasification, Energy Environ. Sci. 3 (2010) 268-278.

[4] K. Babita, S. Sridhar, K.V. Raghavan, Membrane reactors for fuel cell quality hydrogen through WGSR-review of their status, challenges and opportunities, Int. J. Hydrogen Energy 36 (2011) 6671-6688.

[5] F. Gallucci, E. Fernandez, P. Corengia, M.S. Annaland, Recent advances on membranes and membrane reactors for hydrogen production, Chem. Eng. Sci. 92 (2013) 40-66.

[6] K. Ramasubramanian, Y. Zhao, W.S. Winston $\mathrm{Ho}, \mathrm{CO}_{2}$ capture and $\mathrm{H}_{2}$ purification: prospects for $\mathrm{CO}_{2}$-selective membrane processes, AIChE J. 59 (2013) 1033-1045.

[7] J. Zou, J. Huang, W.S. Winston $\mathrm{Ho}, \mathrm{CO}_{2}$-selective water gas shift membrane reactor for fuel cell hydrogen processing, Ind. Eng. Chem. Res. 46 (2007) 2272-2279.

[8] R. Yegani, H. Hirozawa, M. Teramoto, H. Himei, O. Okada, T. Takigawa, N. Ohmura, N. Matsumiya, H. Matsuyama, Selective separation of $\mathrm{CO}_{2}$ by using novel facilitated transport membrane at elevated temperatures and pressures, J. Membr. Sci. 291 (2007) 157-164.

[9] Y.D. Bi, H.Y. Xu, W.Z. Li, A. Goldbach, Water-gas shift reaction in a Pd membrane reactor 
over Pt/Ce ${ }_{0.6} \mathrm{Zr}_{0.4} \mathrm{O}_{2}$ catalyst, Int. J. Hydrogen Energy 34 (2009) 2965-2971.

[10] S.H. Lee, J.N. Kim, W.H. Eomb, S.K. Ryi, J.S. Park, H. Baek Il, Development of pilot WGS/multi-layer membrane for $\mathrm{CO}_{2}$ capture, Chem. Eng. J. 207-208 (2012) 521-525.

[11] J. Catalano, F. Guazzone, I.P. Mardilovich, N.K. Kazantzis, Y.H. Ma, Hydrogen production in a large scale water gas shift Pd-based catalytic membrane reactor, Ind. Eng. Chem. Res. 52 (2013) 1042-1055.

[12] D. Mendes, S. Sá, S. Tosti, J.M. Sousa, L.M. Madeira, A. Mendes, Experimental and modeling studies on the low-temperature water-gas shift reaction in a dense $\mathrm{Pd}-\mathrm{Ag}$ packed-bed membrane reactor, Chem. Eng. Sci. 66 (2011) 2356-2367.

[13] G. Barbieri, A. Brunetti, G. Tricoli, E. Drioli, An innovative configuration of a Pd-based membrane reactor for the production of pure hydrogen, experimental analysis of water gas shift, J. Power Sources 182 (2008) 160-167.

[14] A. Brunettia, G. Barbieria, E. Driolia, T. Granatob, K.H. Lee, A porous stainless steel supported silica membrane for WGS reaction in a catalytic membrane reactor, Chem. Eng. Sci. 62 (2007) 5621-5626.

[15] S. Battersby, M.C. Duke, S.M. Liu, V. Rudolph, J.C.D. da Costa, Metal doped silica membrane reactor: operational effects of reaction and permeation for the water gas shift reaction, J. Membr. Sci. 316 (2008) 46-52.

[16] S. Battersby, S. Smart, B. Ladewig, S.M. Liu, M.C. Duke, V. Rudolph, J.C.D. da Costa, Hydrothermal stability of cobalt silica membranes in a water gas shift membrane reactor, Sep. Purif. Technol. 66 (2009) 299-305.

[17] Z. Tang, S.J. Kim, G.K. Reddy, J.H. Dong, P. Smirniotis, Modified zeolite membrane reactor for high temperature water gas shift reaction, J. Membr. Sci. 354 (2010) 114-122.

[18] S.J. Kim, Z. Xu, G.K. Reddy, P. Smirniotis, J.H. Dong, Effect of pressure on high-temperature water gas shift reaction in microporous zeolite membrane reactor, Ind. Eng. Chem. Res. 51 (2012) 1364-1375.

[19] S.J. Kim, S. Yang, G.K. Reddy, P. Smirniotis, J.H. Dong, Zeolite membrane reactor for 
high-temperature water-gas shift reaction: Effects of membrane properties and operating conditions, Energy Fuels 27 (2013) 4471-4480.

[20] Y.T. Zhang, Z.J. Wu, Z. Hong, X.H. Gu, N.P. Xu, Hydrogen-selective zeolite membrane reactor for low temperature water gas shift reaction, Chem. Eng. J. 197 (2012) 314-321.

[21] H.B. Wang, X.L. Dong, Y.S. Lin, Highly stable bilayer MFI zeolite membranes for high temperature hydrogen separation, J. Membr. Sci. 450 (2014) 425-432.

[22] A. Kulprathipanja, G.O. Alptekin, J.L. Falconer, J.D. Way, Effects of water gas shift gases on $\mathrm{Pd}-\mathrm{Cu}$ alloy membrane surface morphology and separation properties, Ind. Eng. Chem. Res. 43 (2004) 4188-4198.

[23] O. Iyoha, B. Howard, B. Morreale, R. Killmeyer, R. Enick, The effects of $\mathrm{H}_{2} \mathrm{O}, \mathrm{CO}$ and $\mathrm{CO}_{2}$ on the $\mathrm{H}_{2}$ permeance and surface characteristics of $1 \mathrm{~mm}$ thick Pd80wt\%Cu membranes, Top. Catal. 49 (2008) 97-107.

[24] Y.S. Lin, I. Kumakiri, B.N. Nair, H. Alsyouri, Microporous inorganic membranes, Sep. Purif. Methods 32 (2002) 229-379.

[25] M.C. Duke, J.C.D. da Costa, D.D. Do, P.G. Gray, G.Q. Lu, Hydrothermally robust molecular sieve silica for wet gas separation, Adv. Funct. Mater. 16 (2006) 1215-1220.

[26] M. Kanezashi, M. Asaeda, Hydrogen permeation characteristics and stability of Ni-doped silica membranes in steam at high temperature, J. Membr. Sci. 271 (2006) 86-93.

[27] T. Tsuru, R. Igi, M. Kanezashi, T. Yoshioka, S. Fujisaki, Y. Iwamoto, Permeation properties of hydrogen and water vapor through porous silica membranes at high temperatures, AIChE J. 57 (2011) 618-629.

[28] H. Qi, H. Chen, L. Li, G. Zhu, N. Xu, Effect of Nb content on hydrothermal stability of a novel ethylene-bridged silsesquioxane molecular sieving membrane for $\mathrm{H}_{2} / \mathrm{CO}_{2}$ separation, J. Membr. Sci. 421-422 (2012) 190-200.

[29] H.B. Wang, Y.S. Lin, Effects of water vapor on gas permeation and separation properties of MFI zeolite membranes at high temperatures, AIChE J. 58 (2012) 153-162.

[30] M. Hong, J.L. Falconer, R.D. Noble, Modification of zeolite membranes for $\mathrm{H}_{2}$ separation 
by catalytic cracking of methyldiethoxysilane, Ind. Eng. Chem. Res. 44 (2005) 4035-4041.

[31] X. Gu, Z. Tang, J. Dong, On-stream modification of MFI zeolite membranes for enhancing hydrogen separation at high temperature, Micropor. Mesopor. Mater. 111 (2008) 441-448.

[32] Z. Tang, T.M. Nenoff, J. Dong, Internal surface modification of MFI-type zeolite membranes for high selectivity and high flux for hydrogen, Langmuir 25 (2009) 4848-4852.

[33] T. Masuda, N. Fukumoto, M. Kitamura, Modification of pore size of MFI-type zeolite by catalytic cracking of silane and application to preparation of $\mathrm{H}_{2}$-separating zeolite membrane, Micropor. Mesopor. Mater. 48 (2001) 239-245.

[34] X.F. Zhu, H.B. Wang, Y.S. Lin, Effect of the membrane quality on gas permeation and chemical vapor deposition modification of MFI-type zeolite membranes, Ind. Eng. Chem. Res. 49 (2010) 10026-10033.

[35] H.B. Wang, Y.S. Lin, Effects of synthesis conditions on MFI zeolite membrane quality and catalytic cracking deposition modification results, Micropor. Mesopor. Mater. 142 (2011) $481-488$.

[36] H.B. Wang, Y.S. Lin, Synthesis and modification of ZSM-5/silicalite bilayer membrane with improved hydrogen separation performance, J. Membr. Sci. 396 (2012) 128-137.

[37] Z. Hong, F. Sun, D.D. Chen, C. Zhang, X.H. Gu, Improvement of hydrogen-separation performance by on-steam catalytic cracking of silane over hollow fiber MFI zeolite membrane, Int. J. Hydrogen Energy 38 (2013) 8409-8414.

[38] M. Kanezashi, J. O’Brien, Y.S. Lin, Thermal stability improvement of MFI-type zeolite membranes with doped zirconia intermediate layer, Micropor. Mesopor. Mater. 103 (2007) $302-308$.

[39] M. Kanezashi, J. O’Brien, Y.S. Lin, Template-free synthesis of MFI-type zeolite membranes: permeation characteristics and thermal stability improvement of membrane structure, J. Membr. Sci. 286 (2006) 213-222.

[40] M. Pan, Y.S. Lin, Template-free secondary growth synthesis of MFI type zeolite membranes, Micropor. Mesopor. Mater. 43 (2001) 319-327. 
[41] G.K. Reddy, K. Gunasekera, P. Boolchand, J. Dong, P.G. Smirniotis, High temperature water gas shift reaction over nanocrystalline copper codoped-modified ferrites, J. Phys. Chem. C 115 (2011) 7586-7595.

[42] S.S. Hla, D. Park, G.J. Duffy, J.H. Edwards, D.G. Roberts, A. Ilyushechkin, L.D. Morpeth, T. Nguyen, Kinetics of high-temperature water-gas shift reaction over two iron-based commercial catalysts using simulated coal-derived syngases, Chem. Eng. J. 146 (2009) $148-154$.

[43] M. Kanezashi, J. O'Brien, Y.S. Lin, K. Suzuki, Gas permeation through DDR-type zeolite membranes at high temperatures, AIChE J. 54 (2008) 1478-1486.

[44] M. Kanezashi, Y.S. Lin, Gas permeation and diffusion characteristics of MFI-type zeolite membranes at high temperatures, J. Phys. Chem. C 113 (2009) 3767-3774.

[45] J. Xiao, J. Wei, Diffusion mechanism of hydrocarbons in zeolites-I. Theory, Chem. Eng. Sci. 47 (1992) 1123-1141.

[46] M.E. Adrover, E. López, D.O. Borio, M.N. Pedernera, Simulation of a membrane reactor for theWGS reaction: Pressure and thermal effects, Chem. Eng. J. 154 (2009) 196-202.

[47] P. Boutikos and V. Nikolakis, A simulation study of the effect of operating and design parameters on the performance of a water gas shift membrane reactor, J. Membr. Sci. 350 (2010) 378-386.

[48] S. Battersby, B.P. Ladewig, M. Duke, V. Rudolph, J.C.D. da Costa, Membrane reactor modelling, validation and simulation for the WGS reaction using metal doped silica membranes, Asia-Pac. J. Chem. Eng. 5 (2010) 83-92.

[49] D. Mendes, S. Sa', S. Tosti, J.M. Sousa, L.M. Madeira, A. Mendes, Experimental and modeling studies on the low-temperature water-gas shift reaction in a dense $\mathrm{Pd}-\mathrm{Ag}$ packed-bed membrane reactor, Chem. Eng. Sci. 66 (2011) 2356-2367.

[50] G. Xomeritakis, A. Gouzinis, S. Nair, T. Okubo, M. He, R.M. Overney, M. Tsapatsis, Growth, microstructure, and permeation properties of supported zeolite (MFI) films and membranes prepared by secondary growth, Chem. Eng. Sci. 54 (1999) 3521-3541. 
Figure Captions

Figure 1 Schematic diagram of tubular membrane cell (a) and membrane reactor set-up (b) for WGS reaction.

Figure 2 XRD patterns of tubular (a) alumina support; (b) YSZ modified alumina support; (c) silicalite membrane on YSZ/alumina support; (d) ZSM-5/silicalite bilayer membrane on YSZ/alumina support.

Figure 3 SEM images of (a) surface of YSZ modified tubular alumina support; (b) surface of silicalite layer; (c) surface of tubular ZSM-5/silicalite bilayer membrane; (d) cross section of tubular ZSM-5/silicalite bilayer membrane.

Figure 4 Variations of gas permeance and $\mathrm{H}_{2} / \mathrm{CO}_{2}$ separation factor during $\mathrm{CCD}$ modification of the tubular ZSM-5/silicalite bilayer membrane at $450{ }^{\circ} \mathrm{C}$.

Figure 5 Effect of temperature on the $\mathrm{CO}$ conversion $\left(\operatorname{Exp}-M R-X_{C O}\right)$ and $\mathrm{H}_{2}$ recovery $\left(\right.$ Exp-MR-R $\left.\mathrm{H}_{2}\right)$ of the ZSM-5/silicalite bilayer membrane reactor (MR). $\mathrm{H}_{2} \mathrm{O} / \mathrm{CO}$ ratio is 3.0; GHSV is $72000 \mathrm{~h}^{-1}$ (CO flow rate of $\left.30 \mathrm{ml} \cdot \mathrm{min}^{-1}\right)$; Ar flow rate is 30 $\mathrm{ml} \cdot \mathrm{min}^{-1}$; feed pressure is $1 \mathrm{~atm} . E q-X_{C O}$ : equilibrium $\mathrm{CO}$ conversion; Cal-MR-X $X_{C O}$ and $C a l-M R-R_{H 2}$ : calculated result of $\mathrm{CO}$ conversion and $\mathrm{H}_{2}$ recovery, respectively; Exp-TR-X $X_{C O}$ and Cal-TR-X $X_{C O}$ : Experimental and calculated results of $\mathrm{CO}$ conversion of traditional reactor (TR) under the identical conditions.

Figure 6 Effect of $\mathrm{H}_{2} \mathrm{O} / \mathrm{CO}$ ratio on the $\mathrm{CO}$ conversion $\left(E x p-X_{C O}\right)$ and $\mathrm{H}_{2}$ recovery $\left(E x p-R_{H 2}\right)$ of the ZSM-5/silicalite bilayer membrane reactor. Reaction temperature is $500{ }^{\circ} \mathrm{C}$; $\mathrm{CO}$ flow rate is $30 \mathrm{ml} \cdot \mathrm{min}^{-1}$; Ar flow rate is $30 \mathrm{ml} \cdot \mathrm{min}^{-1}$; feed pressure is $1 \mathrm{~atm}$. $E q-X_{C O}$ : equilibrium $\mathrm{CO}$ conversion; $\mathrm{Cal}-\mathrm{X}_{\mathrm{CO}}$ and $\mathrm{Cal}-\mathrm{R}_{\mathrm{H} 2}$ : calculated results of $\mathrm{CO}$ conversion and $\mathrm{H}_{2}$ recovery, respectively.

Figure 7 Effect of GHSV on the $\mathrm{CO}$ conversion $\left(\operatorname{Exp}-X_{C O}\right)$ and $\mathrm{H}_{2}$ recovery $\left(E x p-R_{H 2}\right)$ of the ZSM-5/silicalite bilayer membrane reactor. Reaction temperature is $500{ }^{\circ} \mathrm{C}$; $\mathrm{H}_{2} \mathrm{O} / \mathrm{CO}$ ratio is 3.0; Ar flow rate is $30 \mathrm{ml} \cdot \mathrm{min}^{-1}$; feed pressure is $1 \mathrm{~atm} . E q-X_{C O}$ : equilibrium $\mathrm{CO}$ conversion; $\mathrm{Cal}-\mathrm{X}_{\mathrm{CO}}$ and $\mathrm{Cal}-\mathrm{R}_{\mathrm{H} 2}$ : calculated results of $\mathrm{CO}$ conversion and $\mathrm{H}_{2}$ recovery, respectively.

Figure 8 Effect of sweep gas (Ar) flow rate on the $\mathrm{CO}$ conversion $\left(\operatorname{Exp}-X_{C O}\right)$ and $\mathrm{H}_{2}$ recovery $\left(\operatorname{Exp}-R_{H 2}\right)$ of the ZSM-5/silicalite bilayer membrane reactor. Reaction temperature is $500{ }^{\circ} \mathrm{C} ; \mathrm{H}_{2} \mathrm{O} / \mathrm{CO}$ ratio is 3.0 ; GHSV is $72000 \mathrm{~h}^{-1}$ (CO flow rate of 30 $\left.\mathrm{ml} \cdot \mathrm{min}^{-1}\right)$; feed pressure is 1 atm. $E q-X_{C O}$ : equilibrium $\mathrm{CO}$ conversion; $C a l-X_{C O}$ and Cal- $R_{H 2}$ : calculated results of $\mathrm{CO}$ conversion and $\mathrm{H}_{2}$ recovery, respectively. 
Figure 9 Effect of feed pressure on the $\mathrm{CO}$ conversion $\left(\operatorname{Exp}-X_{C O}\right)$ and $\mathrm{H}_{2}$ recovery $\left(E x p-R_{H 2}\right)$ of the ZSM-5/silicalite bilayer membrane reactor: (a) experiment and modeling results from 1 to 5 atm; (b) modeling results from 5 to 20 atm. Reaction temperature is $500{ }^{\circ} \mathrm{C} ; \mathrm{H}_{2} \mathrm{O} / \mathrm{CO}$ ratio is 3.0 ; GHSV is $72000 \mathrm{~h}^{-1}$ (CO flow rate of 30 $\left.\mathrm{ml} \cdot \mathrm{min}^{-1}\right)$; Ar flow rate is $30 \mathrm{ml} \cdot \mathrm{min}^{-1} . E q-X_{C O}$ : equilibrium $\mathrm{CO}$ conversion; Cal- $X_{C O}$ and Cal- $R_{H 2}$ : calculated results of $\mathrm{CO}$ conversion and $\mathrm{H}_{2}$ recovery, respectively.

Figure 10 Calculated results of $\mathrm{CO}$ conversion as a function of $\mathrm{H}_{2} \mathrm{O} / \mathrm{CO}$ ratio and temperature in the membrane reactor with the feed pressure of (a) $10 \mathrm{~atm}$; (b) $20 \mathrm{~atm}$; (c) 30 atm. GHSV is $72000 \mathrm{~h}^{-1}$ (CO flow rate of $30 \mathrm{ml} \cdot \mathrm{min}^{-1}$ ); Ar flow rate is $30 \mathrm{ml} \cdot \mathrm{min}^{-1}$.

Figure 11 Calculated results of $\mathrm{CO}$ conversion and $\mathrm{H}_{2}$ recovery as function of temperature and GHSV in the membrane reactor with the feed pressure of (a) 20 atm; (b) 30 atm. $\mathrm{H}_{2} \mathrm{O} / \mathrm{CO}$ ratio is 3.0; Ar flow rate is $30 \mathrm{ml} \cdot \mathrm{min}^{-1} ; E q-X_{C O}$ : equilibrium $\mathrm{CO}$ conversion.

Figure 12 Calculated results of $\mathrm{CO}$ conversion as a function of $\mathrm{H}_{2} \mathrm{O} / \mathrm{CO}$ ratio and temperature in the membrane reactor. Ar flow rate is $30 \mathrm{ml} \cdot \mathrm{min}^{-1}$. (a) GHSV is $60000 \mathrm{~h}^{-1}$ (CO flow rate of $25 \mathrm{ml} \cdot \mathrm{min}^{-1}$ ); feed pressure is $20 \mathrm{~atm}$; (b) GHSV is $84000 \mathrm{~h}^{-1}$ (CO flow rate of $35 \mathrm{ml} \cdot \mathrm{min}^{-1}$ ); feed pressure is $30 \mathrm{~atm}$. 
Graphical Abstract

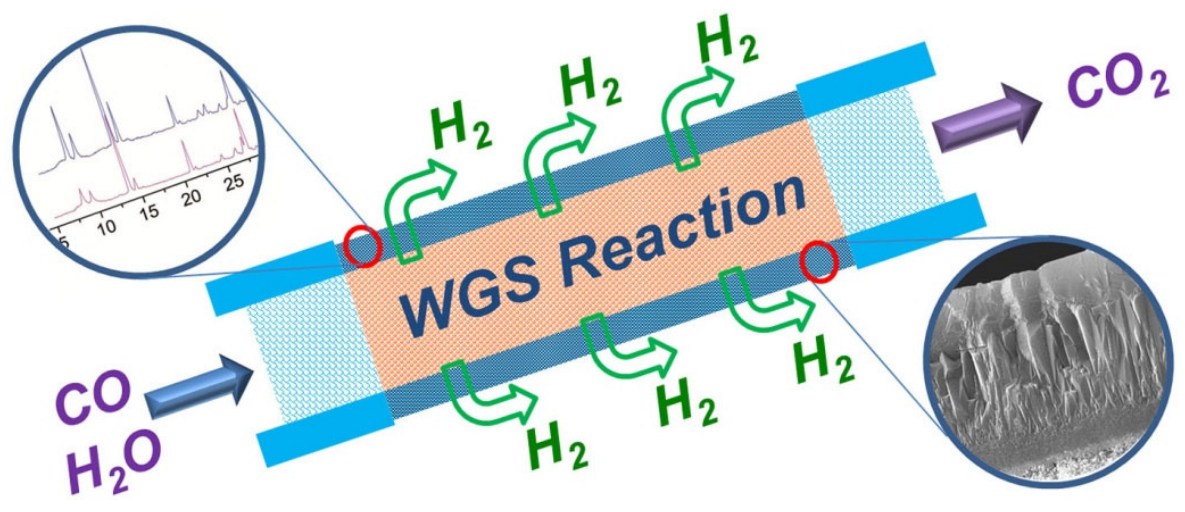

